\title{
Machine Guns: Their Tactics and Equipment
}

\section{Lieutenant G. E. Benson R.A}

To cite this article: Lieutenant G. E. Benson R.A (1888) Machine Guns: Their Tactics and Equipment, Royal United Services Institution. Journal, 31:142, 937-973, DOI: $10.1080 / 03071848809416444$

To link to this article: http://dx.doi.org/10.1080/03071848809416444

\section{Published online: 11 Sep 2009.}

Submit your article to this journal $\widetilde{ }$

\section{山 Article views: 2}


Fridar, Norember 18, 1887.

MI $\triangle$ JoR.Gexer.1 W W. H. GOODkNOUGH, C.B., R.A., InsylectorGeneral of Artillery, in the Chair.

\section{MACHINE GUNS: THEIR I'ACTICS AND EQUIPNENT.}

By Licutenant G. F. Bexsox, R.A.

$\Delta$ GREAT deal has been written of late years about machine guns and the manner in which they may bo employed, but unfortunately the opinions of the various writers rary to such an extent that it appears almost hopeless to arrive at any conclusion ns to their use in civilized warfare without actual experience in the field.

It may, perbaps, be thonght that the subject has been prettr well threshed out, as far as writing is concerned, by the various Offlicers who bave delivered lectures in this Institution; and on that account it appears to be somewhat difficult to find any new suggestions to bring forward which mas be worthy of discussion. In face of this difficalty I proposo during the course of the lecture to repeat briefly the various suggestions that have been made for the use and equip. ment of these wenpons, and give reasons for and against them, before bringing forward my own proposals. I think the great power of machine guns is too universally recognized to require any further illustrations by $\mathrm{me}$, and I will therefore simply state that in practice with a 10. and 5-barrelled Nordenfelt carried on at Bangalore in Angust and September, 1881, before Sir Frederick Roberts, the following results wero obtained :-

'The 10-barrelled gan was found to fire about double the amount of ammunition in a given time (2 minutes), and obtain about the same number of hits, as fifty marksmen and first class shots at 1,200 Jards range.

The 10. nnd 5-barrelled guns firing together for 2 minutes at 2,450 yards gave 192 hiis on a horizontal target out of 855 rounds, while two 9-pr. H.A. guns which fired shrapnel for 9 minates garo 394 hits. The striking velocity of the shrapnel bullets was much greater than that of the Nordenfelt. The angle of descent of the latter was about $20^{\circ}$, so that they would hare reached troops behind earthrorks. It was noted through hout the practice that the 5 -barrelled gun did not hold its own in rapid long-range firing by reason of its want of weight and stalility. This shows that apart from greater rapidity of fire greater accuracy is also obtained from the fraricr 3 ह 2 
class of machine guns. In the abovo experiments the Nordenfelts were worked by unskilled men.

About a rear ago a pamphlet on this subject was written by a M. Gustar lloos, at St. Petersburg, and he informs us that experi. ments in Russia hare shown the following results :-

(1.) One 5-barrelled Nordenfelt $=50$ men.

(2.) At 950 sards a single machine gan produced a greater effect than two ficld or mountain guns.

(3.) From 950 to 1,700 jards a singlo machine gun produced the same effect as two field or mountain guns.

He lays great stress on the laying mechanism enabling fro to be continuous and effectire when the front is obscured by smoke or darkness, and this I fonnd to be of great importance in the Soudan, when laying theso guns beforo nightfall, so as to sweep the ground in case of a night attack, thus making sure of the fire being effectire in the darkness.

'Ihe tro great questions on machine gans are these:-

lst. What should be their neans of transport?

2nd. To which arm of the Service are they to be nttached?

The answers to these two questions are dependent on each other. If they are to be attached to the monnted brinches they must bo ablo to get over the ground quickly enough to accompany thern on service. For this purpose pack transport appears unsuitable, as it entails men marching on foot to lead the aninals. Apart from this, pack transport lins the following disadrantages:-

(1.) A long train of pack animals would be required to carry suff. cient amnunition for one machino gun; for an animal can only carry on his back one-third of the weight he can draw at speed.

(2.) Tho heavicr class of machine guns producing tho best shooting (as shown by the Bangalore experiments) would be too heavy to mount on a pack animal.

(3.) The delay in coming into action and moving them short dis. tances.

In my opinion one of the most important considerations in deciding on the method of transport of machine guns is the carriage of ammunition. Some men lave urged that it is a mistake to imagine that such a large supply is required with machine guns, as they never hare to fire rapidly for a long period, and in support of this theory it is pointed out that in the recent operations in the Soudan is comparatively small amount was expended. But it is forgotten that the most important fghts where they have been used seldom lasted moro than half an hour, which is rery different from the duration of a battle between tro civilized Porrers. Suppose jou have a machiue gun on pack animals, as suggested by Major Anderson, R.W.A., in a lecture recently delivered bere; ${ }^{l}$ according to his plan, one mule is for the gun and the other for the ammunition, while a reserve of ammunition is to be provided for elsewhere. $\Lambda$ s this ammunition mule can only carry about 1,000 rounds the supply would be totally 
inndequate, and the gun wonld be uscless till the reserre ammu. nition succeeded in finding its way to the spot. On the other hand, if you have a string of ten mules to carry the 10,000 rounds per gun which are necessary eren for the lighter natures, think of the number of men required to lead these mules, the size of the mark they would offer, and the space they rould occupy on the line of march when this namber is multiplied by the number of gans, in addition to which these long strings of pack animals are most unwieldy for mancurring. With the gun and nmmunition on wheels inany of these disadrantages disappear, for (1) a heavier and thereforo more powerful and acenrate gun can bo carried, (2) a larger amount of ammunition can be carried actunlly with the gun. (3) If drawn by horses, great rapidity of movenent is attrinable in sucl country $n$ campaigns between civilized Powers generally take place in. (4) Tho limbers and axlctrees afford seats for the men who with pack trans. port must march on foot. The principal adyocate of this kind of equipment has hitherto been Lord Charles Beresford, who recommends it as combining great rapidity of movement and a plentiful supply of ammunition.

It has been suggested (notably by Captain Armit. ${ }^{1}$ ) that theso weapons should be mounted ou light carriages drawn by" infantry. The arguments ngainst this method are, I think, patent to everyone. The most obrious are:-

(1.) The enormous labour of dragging these guns in a campaign. Men usually hare enough to do to drag themselres along without making them pull a gun as well, and their strength may be far moro usefully applied than by turning them into draught animals.

(2.) Sulticient ammunition could not be carried with the gun.

(3.) This style of draught would give the machine guns the lenst possible mobility, while what is required for every arm is the greatest possible mobility.

Another system, which is now being tried in soreml caralry regiments, is to mount the gan on a two-wheeled limber, with the ammuuition underneath tho gun. It is intended to be fred without unhooking the horses by two men on the limber. This system has certain points in its favour-notably its mobility and readiness in coning into action. But I think a good many will agree with me in urging the following objections to it:-

(1.) That sufficient ammanition cannot be carried, probably. not more than 2,000 rounds at tho outside, which would not last moro than six or seren minutes in rapid firing.

(2.) The breathing and motion of the horses would impair the accuracy of the fire; anyone who has seen a batters of artillery after a gallop for half a mile will rendily understand how the blown horses move the limbers. 2

(3.) Supposing a horse were hit, the gun would be put out of action

1 Journal, No. 133, p. 37.

2 This objection has been met by Jrr. Norlenfelt by taking the weight of the shafts off the horses by wedns of a prop on coming into action, but this does not affect the other objections in any way. 
till the horse ras extricated. The limber may act as some sort of protection from frontal fire, but not when firo becomes in the slightest degreo oblique, and the gun might thus be put out of action at the moment wlien its fire is most wanted. Besides this, the mere falling of bullets or shell near tho horses would cause them to become nu. steady and spoil the shooting.

(4.) The grun eaunot be detached from the limber to bo run up into a position, either where horses caunot go on account of rough ground, or where it is desired to ran the gun up the reverso slope of a hill just far enough to be able to fire over the top and not be seen by tho enemy when coming into position. If the horses take them up under these circumstances they would form a large object with tho limber and prohably be seen at once.

(5.) Difficulty in getting corer for the gun thus mounted when used in the defenco of positions, for the great height of the gun from the ground (nearly 6 feet), and the size of the limber would make a rery larre epaulement necessary to hide it. On the other hand, of course, the extra height would enable it to fire over a ligher parapet which would givo moro corer to the men.

Now if we pat the gan on an ordinary light gan-carriage with a trail hooking on a limber tho abore objections disappear, for an in. creased amount of ammunition can be carried by means of axletrec boses on the carriage, while the limber, no longer hampered by the gun on top of it, could carry an increased number of ronuds. The gun would bo fired with the trail resting on tho ground, aud could be one of the most powerfal class. The importance of this latter consideration is sufficiently seen in comparing the practice of the 5-and 10-barrelled Nordenfelts at Bangalore in the experinents previously referred to, the 10-barrelled gun proving itself more than twice as powerful, and more accurato at long ranges than the 5-barrelled gan. It is also evident that the horses could be placed under better corer, and when ono was struck it would not interfere with tho fire of the gun, as in the case of the gun being mounted on the limber. The gun could also be detached from its limber and run up into positions required, sas, up tho steep rererse slopo of a hill, while the horses and limber would remain under corer farther down the slope in rear.

Tho chief objection urged against this method of mounting is the weight and consequent number of animals required to drag the gun, and the consequent expenso in equipping them. But I will endearour to show that though this method is apparently the most expensive, it is in reality the mest economical. Fior the sake of argument wo will take the Nordenfelt 10. and 3-barrclled guns, and assumo that the heavier gun with its 10 barrels is only three times as powerful as the 3-barrelled gun, thus making threo 3-barrelled guns capable of delivering the same amount of firo as the singlo 10-barrelled gun. The latter, weighing over 2 cwt., cannot bo carried by pack animals, whilo from its breadth it cannot bo monnted on a limber without taking up most of the room required for ammanition. The 3-barrelled gun is tho kenpon recominonded for pack transport and for mounting on a limber. The 10-barrelled gun mounted 


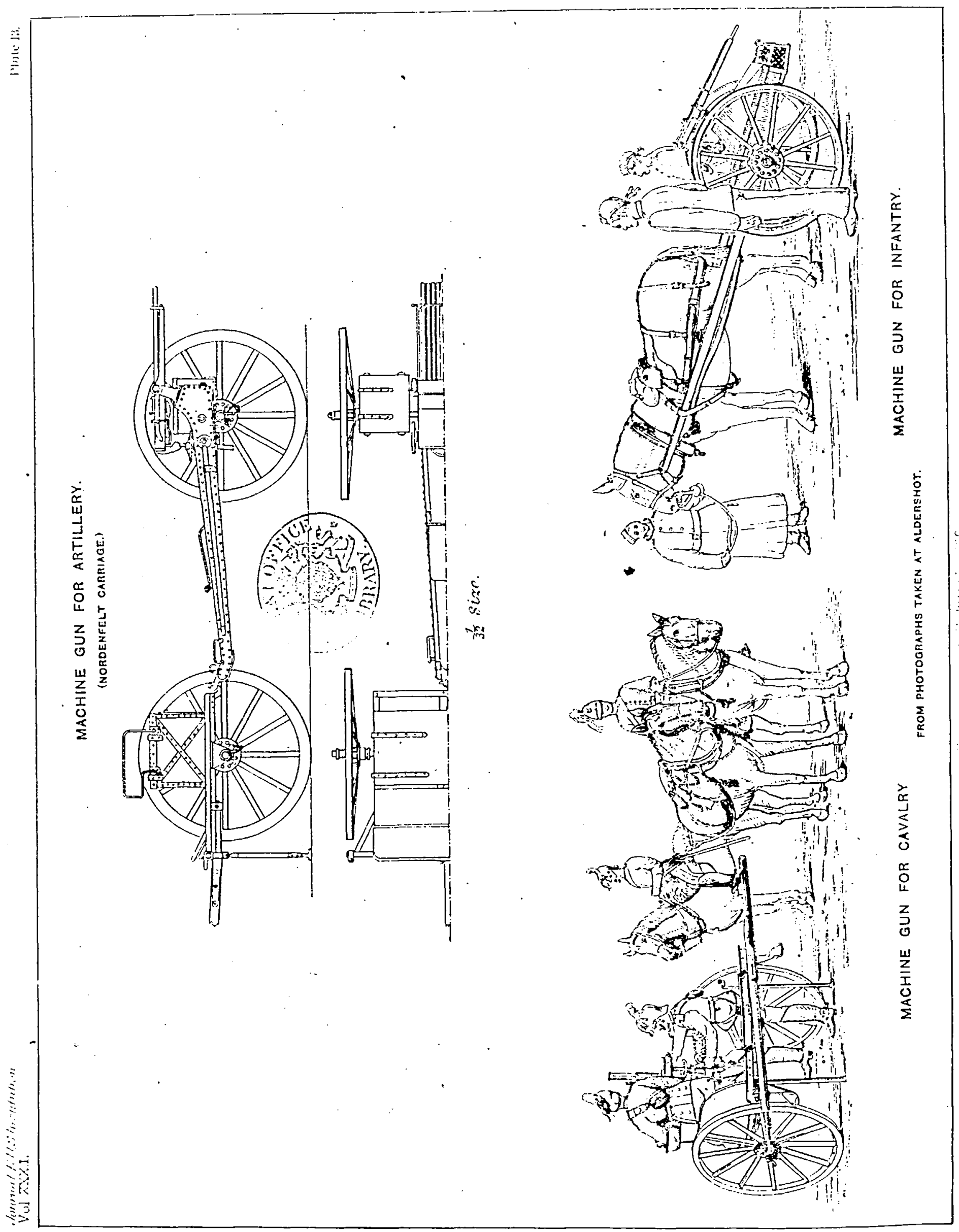


on a field carriago with limber, the whole carrying 5,000 rounds and three men on the boxes, weighs about 25 cwt., and therefore can be drawn at speed by four horses. Add a horse for a N.C.O. in charge, and wo have a total of five horses, one N.C.O., three men on the seats, and two drivers. A 3-barrelled gun mounted on a limber has with it 1,546 rounds and two men, takes two horses to drag it and one N.C.O. on another horse to look after it. Three gans mounted like this, having altogether 4,638 rounds, will therefore take-

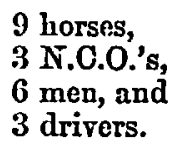

Thile in the former caso we have-
5 horses,
1 N.C.O.,
3 men, and
2 drivers,

thus showing a saring of four horses, two N.C.O.'s, three men, and one driver. This is a very considerable saving; while as regards space occupied on the march, in camp and on the battle-field, and ease of control of fire, the single powerful 10-barrelled gun has an immense adrantage over the more numerous but less powerful 3-barrelled gans. Comparing the same gans when the 3-barrelled gun is carried on mules, the advantage of the 10-barrel is still more decided, for four mules are required foi the gun and carringe and about 1,500 rounds, thus making twelvo mules necessary for three such guns, whilo at least six men per gun or eighteen in all would be required for mounting and dismounting the gans ard looking after the mules. Wo thus have eighteen men and twelve mules against six men (two drivers) and fire horses. Of course a much larger supply of ammunition than the amount aboro mentioned is necessary, and this must be brought up on whecls unless the country is impracticable, in which case the organization would bo more that of a mountain battery. Yet another point in farour of the gun-carriage and limber principle is that yon have a good supply of ammunition close at hand, the immense importance of which is fully brought out and impressed on us by Prince Hohenlohe in his letter on the supply of ammunition during the wars of 1866 and 1870-71, recently published in the R.A. Institation papers.

Having argued out the question of transport thus far, and fixed on a style of carriage (see Plate) which combines three great desiderata, viz., (1) extremo mobility; (2) considerable ammunition supply; (3) a steady platform from which to fire the gun, we now come to consider the tactical organization of these weapons. In order to do this properly, it-will be necessary to, so to speak, analyze the fire of machine guns.

Without again going into the detail of any experiments, I will point out the following characteristics of their fire:- 
(1.) The great power of concentration and rapidity of fire, which enables them to do a great deal of damago at a giren point in the shortest possible time.

(9.) Power of turning the stream of fire at will in ans direction required during the actual firing.

(3.) The continuity of their fire, i.c., the fire goes on continuously without any stop for laying after evers round as in the case of the infantry riflo and the field gun.

(4.) The great control of fire, owing to the whole of the firing in cach gun being done by one man.

'The first of these is equally characteristic of artillers, and is due, generally speaking, to the fact that in a battery, taking a gun as a unit, there aro only six units to direct; whilo in a battulion there are 1,000 units or so, of which perhaps 800 arc in the fighting lino; and here the front over which they are extended is much greater than in a batters, thus making supervision still moro diffealt. No. 2 is a characteristic belonging to machine guus alone. No. 3 belongs only to a machive gan as a weapon, but this continuity of fire is of course also attainable by the other arms when there is a sufficient number of then. No. 4 applies equally to artillers and machine guins, and results from the small number of units in one command.

From the abore we gather that there are some uscful qualities pertaining to inachine-gun fire which are not shared equally by that of the other arms, and it therefore behoves us to uso these weapons in such a way as will bring out these qualitics and make the utmost use of them. Tho effect of fire is said to depend on two things, riz.: (1) its suddenness; (2) its intensity. The latter is a quality evidently possessed by machino guus, bat it has not necessarily the former, as the suddenness depends on the eircumstances of the case, and whether. it is expected or not. Clearly then to make this fire unexpected and sudden, it is necessary to make the werpons as mobile and as capable of rapid movement as possible, so that they may be placed in the required spot at the required moment, which means practically, if accom. plished, that their fire will be sudden and uncxpected by the enemy. For iustance, they might be required to gallop off in order to check an attack at a threatened point, or seize a favourable opportunity for enfilading the line of the enemy, whether of gans or infantrs. The intensity of their fire makes them capable of doing such an immense amount of damage in a short time that their power of rapid movement. increases teufold their power and mornl effect. There is still nnother point about these weapons which I think is worth noting; it is the difficults of distinguishing their position at long ranges when infantry are firing alongsido of them. T'o illustrato this I may mention that. at the Easter sham fight at Dorer this year, I was with tbe attacking force, and when my battery camo into astion in the most adranced artillery position, about 800 yards from the defenders, I could distinctlyhear the well known rattle of their Nordenfelts, but could not be certain where they were, as the smoke caused by them was the same as that caused by'the musketry fire, whereas the smoke of artillers, eren at a much longer range than this, at once betrays the position of 
the guns. If smokeless ganpowder could be introduced, it is evident that the position of the machine-guns rould be still more undis. tinguishable.

I think I may assnmo that the value of these weapens in the defenco of fortresses and fortified positions is too universalls recognized to require further comment. It is their ase in tho open field about which there is so much coutroversy.

No doubt in 1870-71 they were a failure, but their failure is attributable to the following defects :-

(1.) Tho imperfect nature of the reapon ased.

(2.) Want of training on the part of the men. They took the guns direct from the arsenals to the field of battle without any previous training.

(3.) Irisnpprebension of their tactical use. They seem to lave been placed in line of battle to contend with artillery at ranges at which their orn firo was comparatively powerless, and were thus easily destroyed instead of being reserved under corer for ranges where their fire would be more effectivo. As in most of the battles in that war the French stood on the defensive, we haro no example of their being used on the offensire.

Tho ranges at which machine gun fire is most decisire in its effects compared with that of other arms are probably those between 800 and 1,600 sards, and in futurc wars it appears that battles are not unlikels to be decided at those ranges. Under 800 jards the power of infantry firo increises rery rapidly, and over 1,600 yards that of machine guns diminishes so much that they would bo overwhelmed by artillers fire. Thas the machine gun cannot supply the place of skirmishers nor yet that of artillers, but would play a very special rôle when oceasion required, whenever itcould be brought into the required position at the right moment. AC. Gustar Roos supports this theors and says that"Tho machine gun constitutes a special arm, haring its own definite sphere of action, within the limits of which the enemy is strack in the most advantageous manner by the weight of metal projected, and with a smaller loss of time and men than in the employment of anj other arm whateres:"

I think it is pretty plain that if I have correctly analyzed the fire of machine gans thero are sereral rery important differences between the condact and control of that firo and that of infantry; in fact the only point in common appears to be thist they both fire bullets of the samo pattern; for I maintain that thero is a very important difference in the effective ranges of tho rifle and the machine gun when the former is handled by largo bodies of men which are very diffienlt to control in extended order in the excitement of the battle. MInchine guns can, from the control under which they mas be heid, open fire with effect at ranges where a rery large proportion of the infantry ammunition would be wasted. In this control of fire and power of concentration on one object they resemblo artillery, but hare not sufficient range to contend successfully with that arm except under certain conditions. A point where they have the advantige of artillery is that there being no recoil, they can come into action on a stecp 
reverse slope where, if field guns were fired, the recoil would send them to the bottom of the hill. The fact that they can keep up an effective fire when the front is obscured by smoke or darkness, provided they havo been previuusly laid, has already been noted. They also sharo with artillery the bad quality of powerlessness during movement, for anjone who has sat on a limber going at speed orer rough ground will realize the impossibility of firing when in movement. 'The men have cnough to do to hold on without haring to fire a gun as well. Irachine guns can, however, from the simplicity of their ammunition, come into action quicker than artillery.

With cavalry the machinc gus has nothing in common except, perhaps, its power of rapid morement, for savalry are supposed to act by shock while machine guns act by fire alone.

Since these reapons have so little in common with the other arms, it might appear that wo aro as far off as ever from settling the question as to which arm this weapon is to bo attached. On the contrary, I think we are now near a solution of the problem.

Caralry and artillery are generally recognized as the anxiliary arms, the use of the former being to gain information on which the infantry may act, to protect the flauks of the infantry when engaged, and to pursue the enemy when beaten by the infantry; the use of the latter being to prepare the way for the infantry by bombarding the enemy's position, and to follow up the enemy's retreat and convert it into a rout by the fire which is brought into play by means of their rapidity of movement. Therefore naturally we mast look on machine guns as , another auxiliary arm invented by modern inerenuity, just as cannon were invented by the ingenuity of men some centuries ago and made part of the fighting forces of the period.

I et us examino the different starges of a battle, and note the various róles of hlie machino guns in cach stage. As the two armies approach each other the hostile cavalry mect. This is the preliminary or reconnoitring stage, and one drives the other in till cliecked by the encmy's infantry. Illachine guns can eridently be given the mobility necessary to accompany caralry, and their rapidity of firo and readiness in coming into action would enable them to act with the greatest effect during the rery short timo the hostilo bodies are in the act of approaching cach other before charging. In conjunction with horse artillery and dismounted caralry, they might even drire back the first infautry outposts of the enemy met with, tho machine guns approach. ing to effective range, corered by the fire of the horse artillers.

During the preparatory stage of the battle, when the artillery are oombarding the enemy's position, the machine guns might be drawn up écheloned in rear of the flanks of the line of guns, themselves out of fire, but able to prerent by their fire any dashes mado by bodies of the enemy's cavalry on the flank of the guns. When the cnemy's attention was thoroughly engaged by the artillery ducl, and the battlefield obscured by smoke, opportunities might cceur for them to mako a dash forward, accompanied by carnlry, to close range, if possible on a flank, and if successful the damage done to tho enemy's gun teams and gunners in a very short space of time would probably 
be enormous. Howerer, they cannot well bo used against artillery with success unless they can take it by snrprise or in flank within 1,700 yards or so; but under these conditions the dismiay and confusion this sudden hail of lead would eause can well be imagined.

Modern firearms and discipline havo made it more than erer necessary to beat down the comrage and reduce the numbers of the defenders of a position before the infantry can advane to the assault, and in this duty machine guns could render important services in the later stages of the bombardment when the artillery of the defence is more or less silenced. When this is nccomplished, the machine guns might appronch to a range of from 1,200 to 1,600 gards with com. paratire impunity, and from a position on the flank of the line of their advancing infantrs, they could pour in a storm of bullets which would senrch out the defender's shelter trenches, and could not but cause many casualties. It is probable that the supporting fire of machine guns could be kept up longer than that of artillers, as there is no such variable quautity as a fazo to be taken into consideration with the former wenpon, and thus the infantry would receive moro support at the time it is most wanted. Wlien their fire is masked, they would turn their attention to bent off counter-attacks, and firo on other supporting bodies of the enemy till a foothold was obtained in the position. Then they would advance, as the artillery do, to confirm the success of the infantry, and hold the position gained till tho infautry had again been got into hand. Their mpidity of morement, readiness in coming into action, and continuous murderous firo would cnable them to do this most effectively, and perhaps in no other rôlc will their effect be more felt than in this. At this and other periods of the battle no doulst great opportunities would occur at times when mathine guns could advance close up and sustain their warering infantry at critical moments, just as the German artillery did in the war of 1870-71, by firing case and shrapucl with the fuzo bored rery short; but the superior man-billing power of the machino guns at these short ranges, and the fact of their being smaller marks to tire at-haring a less number of horses and men for the samo namber of gans-would make them appear most suitable for such tacties.

In pursuit of the enems, or retreat in face of the enems, the above-mentioned qualities will serre in great stend the army which makes ase of these weapons. At this last stage the defenders, whether retrenting or being driven ont of their position, or advancing after having repelled the attack, will generally bo in fairly close formation, and thus make tho close and concentrated fire of machino gans most deadly.

In the manner I have indicated, they might perform eflicient service to all arms in turn. In order to be always on the spot for tho carrying out of these duties, it might appear necessnry to attach them to all three arms, or at any rate to the infantry and caralry. But this would make it necessary to havo too great a number of them altogether, and therefore for the sabe of economy and simplicity it appears advisable to hold them under the hand of the General in 
command of cach Dirision, so that they might be told off to work with each arm as might be required. In fact they should act in conjunction with whaterer arm happens to be playing the most important part in the different stages of the fight-with the caralry in the preliminary stage, with the artillery to protect thcir Ianks in the preparatory stage, with tho infantrs during their adrance and assault, and again with the caralry for the pursuit or mostreat.

In order to use them in this way they wonld hare to be organized in troops of say four gans ench. I say "troop" in preference to tho word "battery," becnuse a "battery" expresses a force which batters or boubards inaterial obstacles, whereas a machine gnu is only a mankilling weapon. Each troop wonld consist of four guns and fonr ammunition wagons or carts, which should always accompany tho guns on the line of march. Prince Hohenlohe in his letters lnys great stress on this for artillers, and his reasoning rill apply equally to machine guns. The guns would require four horses each, and if wagons similar to artillery ammunition wagons were employed they would require the same number, but probably a light S.A.A. cart drawn by two horses would be preferable, though of course the nmount of ammunition carried would not be so great.

I have reckoned the war strength of a troop as abore described to be as follows, allowing for store wagons, spare horses, \&c.:-

With ammunition wagons.

IIen. $\begin{gathered}\text { IJores. } \\ 54\end{gathered}$

With ammunition carts.

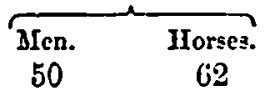

Three such troops might be attached to each Dirision, and perhaps wo to the caralry Division, making eleven troops per army corps.

Tho war strength of threo troops, with arnmunition carts, would be (allowing one forge and six horses per three troops) -

$\begin{array}{cc}\text { Jien. } & \text { Horses. } \\ 153 & 192\end{array}$

For purposes of comparison I mas say that the war strength of a battery of horse artillery is-

IIcn. Horses.

Probably a peace strength of thirty horses per troop would be sufficient. Each troop would be capable of delivering $n$ fire of 4,000 rounds per minute, though it would bo seldom that this rate of fire would be required.

I don't know how many rounds the fighting lino of a battalion of infantry could fire by villegs per minute without getting out of hand, but probably it would be about 1,500 rounds, allowing about five rounds per minute to crers man in the fighting line.

Attached to the cavalry Division in front of an arms, the ralue of 
such troops of machine guns is andeniable for holding important points seized by the cavalry before the infantry come up, and for acting on the enemg's caralry just before tho charge as previously pointed out. They would furnish the fire power which no doubt is now necessary to accompany caralrs, and to provide which it is thought adrisable to organize conps of mounted infantry, though, if the Jitter are also to be used for outpost duty and scouting, machine guns could not of course supplement their dutics in that respect.

In support of the abore riers I will quote some of the remarks made by Colonel Andrewes, R.H.A., who was present at the experiments carried out at Bangaloro previously referred to. Among other things ho says:-

"That their power of mobility on carriage or pack transport would admit of their taking an important part on special occasions with caralr's or mounted infantry in holding bridges, fords, causcwass, \&c., \&c., pending the support of infantry, and that they would also prove of good value on outpost.

"That they should hare a distincl organization, each gun being under a well-approved warment officer, and that they should take their place with any force in the field massed in battery under a Staff Ofticer, parked with the corps artillery, and held at the immediate disposal of the General Commanding, for distribution by him to regiments of infantry or cavalry as occasiou might present, or for disposal at his discretion at any critical and suitable timo or place.

"They would appear to have their grentest ralue on tho defensiro as a multiple of infautry fire, against assault of position, entrenched or otherwise. Their moral effect is great, and should it be ultimately decided to attach them more permanently to battalions, I think thes would occasionally prove a raluable ausiliary to infantry and artillery in co-operation, by falling back to the positions taken up in succession by the latter arm to cover a retrent, and offer rallying points for the force."

With reference to the first part of this last paragraph, I may remark that it is an axiom laid down in all works on tactics that all firearrns are more powerful on the defensive, and I don't sec any reason why the ralue of machine guns on the defensire and offensive respectively should vary any moro than that of other man-killing firearms.

The abore sketch of the tactics of machino gans principally deals with their use on the offensive, about which perhaps there has been more controversy than ou the defensive, for overgone, I thint, recognizes their great value in the latter case.

Their tactics in a battle fought on the defensive would be somewhat as follows: In the preliminary stage the defender's cavalry would probably be weaker than the attacker's, but the presence of a few machino guns with tho former used as beforo described might prevent the latter gaining much adrantage. When the defender's cavalry fall back on their infantry outposts and adranced 
posts the machine gans would certainly cheuk the enemy's adrance, the chicf point to be obserred being that they should remain as far as possible under cover until the enemy, whether infantry, cavalry, or artillers, should approach within effective machine-gun range, for if they fire at long runges against the attacker's artillery they: would be liable to be destroyed. If ordered to retire on the main prosition their services there would be rendered much in the same way. Further comments on their use on the defensive are perhaps unnecessary, but it may be expected that their great mobility would be turned to good account in malsing counter-attacks on the flanks of the attackers, and in enibling them to be held in central positions intact till it is absolutely certain on which points the enemy's main attacks will be delivered. If these weapons were drawn by infantry on light carriages these rapid changes of position would be quite impossible, and their sphere of action would therefore be very limited. Amid the dust and smoke of a battlefield these morements would not readils be noticed till a stream of bullets would suddenly appear from an unespected quarter, and once the range is found, a few minutes' fire from these reapons means annihilation.

Long-range infantry fire has of late assumed an importance bitherto unthought of, bat there are so many disadrantages connected with it, e.g., in the men getting out of hand and the expendi. diture of ammunition when it is difficult to distribnte a fresh supply among an extended line of men under fire, that tho uso of this fire is by no means an unmixed alvantage. Perhaps machine-gun fire is the best sort of long-rango infantry fire on account of its greater accurace and the conplamtire case with which the supply of ammunition can be renewed, as it has not to be distribated auong so many units.

Proposals liare frequentls been made for making machine guns actually part of an infantry battalion and cavalry regiment. It is proposed to attach a certain number to erers infuntry battalion, in order to supplement the fire of the battalions, because a machine gun is called a cluster of rifles, but we have never yet heard of anj sound scheme for their use in action when so attached. They cannol possibly accompaus the shooting line of the attackers in action, for they would at once become a conspicaous mark for the defenders, as they canuot lie down and fre as infantry do. Moreorer, if carricd on males and the males be shot, the gun would be practically useless, as it could seareely te expected that the men would bring it along, and then again comes the question of carrying a large amount of ammunition under close infantry fire. If mounted on whecls and drawn by mules or horses, it would soon be rendered stationary by the samo fire; and the reasous why it cannot be drawn by infintry hare already been given. On the other hand, if placed to a flank about 1,000 to 1,500 yards from the enems to perform its functions as longrange infantry fire covering the adrance it would be an long way from the battalion it belongs to, and therefore completely out of control of the Oflicer commanding the battalion. If worked thes awny from the battalion, the Cummanding Oflicer would have to detach from his 
probably alrendy too weak battalion a certain number of Officers and men to look after weapons orer the service of which he would no longer have any control. This idea is simply a reviral of the old battalion gun system which was proved long ago to be entirely vicious.

Again-suppose the battalion to be neting on the defensive-the machine guns rould be placed to defend special points, snch as salients, to sweep roads, $\delta$ e. In this case is there any advantage in having them as part of the infantry battalion? I say certainly not, for they would perform those duties equally well if they did not belong to the infantry. Would it not rather be probalile that if belonging to a battalion in a defensivo position, and that battalion were to becone unsteady, the same unsteadiness would affect their comrades with the machine guns, wherens if thes were distinct from ench other there would be a sort of rivali's between the riflemen and the machine gun men as to which would hold on to the position the longest. Much the same lind of reasoning applies to the case of theiv being attached to regiments of caralry. If they are to be used with caralry, as I saw the gun of the 10th Hussars used the rother ding at the Agriculturnl Hall, riz., to firo on the encmy's cavaly's from a flank just before the charge of tho two hostile bodies, why should not horse artillers be so attached, and jet if such a thing were proposed it would be reccired with ridicule.

Inngine a cavalry regiment sent off on reconnoitring duty orer rery rough country, which though passable for horses was so in a much less degree for wheeled carriages, or ordered on any duty where machine guns were not required. What would the regiment do with its machine guns? It unust either leare them behind, in which case the regiment inust be split up, or else they would hamper the morements of the rest of the regiment by causing it to wait for them in diflicult places, or thoy would hare to sarry them on pack animals, in which caso a total ebange of their equipment would be necessary, at the expense of having a greater number of animals than ever.

It was once proposed to attach them to batteries of artillers. But I believe this project has long ago been given up. In fact it was most probably this very proposal which led ganners in the first place to set their fnees against these wenpons.

Such organizations as these are opposed to all the lessons of war and to all ideas of that simplicity which is so essential in warfare the Officers and men of such corps would be required to know every. thing about their arms, and thus their work would be doubled, or alse the special Officers and men selected for the machine guus would be left to themselves, and practically constitute a separate unit.

In addition to this the principlo of concentration of fire of soveral machine guns at once on certain localities must be kept in view, and it could not be managed if in order to do so it mere necessary to collect the scattered little machine guns from the various battalions aud regiments, for that would take up valuable time, and even when massed togrether (as suggested in Major Anderson's lecture) the want of previous practice in working together would make proper 
regulation and control of fire an impossibility. It is casy enough to get forces to act separately which hare been trained to act together, but it is a very different matter to get those to act together who have only been taught to act separatels.

T'heir method of working when supporting their infantry would probably be sometling after the mode at present recommended for artillery, viz., to direct a concentunted anniluilating fire in turn on the rarious portions of the line to be attacked. I'ile necessary fire discipline to accomplish this would be absolutely unattainable with a heterogencous mass of little machine guns from the rarious battalions without any organization in units or any chain of responsibility. The three powerful troops of divisional machine guns that I suggest would deliver a fire equal to that of three dozen of the light machine guns which could be carried on mules or pulled by infantry, while in the fire discipline of the two forces and the space of ground occupied, there would be no comparison. Again, after the action was over, imngine these unfortunate machine guos attempting to join their regiments and battalions again in tho con. fasion of victory or defeat. Of course in thinking out these things we are obliged to bring such practical considerations as these to the front as well as theoretical ones. To those who have read the accounts of modern European wars, it appears quite possible that the poor little machine guns would not find their own battalions till some days afterwards.

In the foregoing pages I have been treating almost exclusirely of warfare against civilized nations in the fairly open country where it is usual for campaigns to take place.

In fighting in uncirilized countries against sarages these proposals would have to be largely modified according to the practicability of the country and the nature of the savage tactics. For instance, against such foes as fanatical Arabs or Zulus who almost invariably act on the offensive, thus causing us to act on the defensive, the offensire power of machine guns is not required to be made much use of. In addition to this the barren and impracticable nature of the country usually compels the number of transport animals to be cut down to the lowest possiblo limits, and the short duration of fights against charging sarages renders it unnecessary to havo so large i supply of ammunition with the gun. Therefore, we must hare an equipment suitable to these clianged conditions. If pack transport alone can be used something in tho nature of mountain battery cquipment would meet the case, and the gans wonld hare to be lighter and less powerful. As the ranges at which these sort of fights takes place are usually short the inferior accuracy of these light wenpous at the longer ranges would bo of little consequence. It mould be advisable, however, whenerer the nature of the country permitted it to have the guns and anmunition drawn on whecls on account of the consequent saving in animals, and as they would usually be used on the defensive it would not be so necessary to giro them the great rapidity of morement which is so useful in civilized warfarc. 
Captain W. N. Lloyd, R.A., organized a troop of four Gardner guns on the mountain battery principle during tho recent operations in Burmah, and an interesting acconnt of the equipment of this troop was sent by him to the Royal Artillery Institution papers some months agro. In it he recommends for the four guns an establishment of afty-two Offecrs and men besides a nativo establishment for the mules. 'This, ho remarks, is about half the establishment required for a 4-gun mountain batterg. He points out the great value of tho machine gun fre for scarching out the position of the dacoits in the jungle and for playing on their line of retreat when driren from tlicir stockades or villages, and I hare General Sir G. White's word for it that these weapons did good service when called upon.

In conclusion, I would point out that it is of little use our writing and talking about machino guns and making proposals for their equipment and tactical use, unless wo take measures to havo these proposals tested by experiment as far as can be done in time of peace. It is also of little ralue trying one gun here and another there without any nttempt at making them work together; what we want is to try thoir combined effect ander serrico conditions and at targets representing such objects as would be fired at on scrrice. Mforcover, the N.C.O.'s and men must bare some preliwinary training before conducting any experiment, in order to make it a fair trial, and trained range-finders must bo supplied, for without them there is considerable difficulty in finding the range on damp soil or turf, though on dry soil the dust knocked up by the bullets is suficient guide. This difficulty in finding the range is no doubt the chicf bar to the efficiency of machinc-gun fire. 'To obriate it perhaps some small gun firing an explosive shell might be carried and used to find the range just as common shell are used with artillery. With the equipment and training of men complete we conld compare the effect of machine-gnn fire with that of iufantry and artillery at the various ranges, and from tho rosults obtained get a more correct ider of their valuo in tho field whether ased singly or working together. In order to accomplish this I haro the following suggestions to make : There are a large number of 4-gun batteries in the artillery armed only with the obsolete 9-pr., which we may be pretty sure will never again be sent on service. Sappose these gans be taken away from one of these battcries for a time, and machine guns supplied in their places; there would be suficient horses and men in one battery to fit ont two machine gan troops for experimental purposes; after a little training a regular series of experiments might be carricd out as far as possible under service conditions against targets representing troops of all arms and in various formations, men in shelter trenches, \&c. I'his experiment would cost littlo boyond the fitting up of the gaus and carriages and the expenditure of ammunition, and could not bat bo most interesting and valuablo in its results.

In adrocating the use of machine guns in the field, I wish it to be distinctly understood that $I$ do not consider that they can supply the place of either infantry or artillery except under certain conditions, bat that by their own peculiar power at certain ranges they may

TOL. IIII. $3 \mathrm{~s}^{\circ}$ 
decide a battle in favoul of tho army which possesses and linous how to usc them. I, therefore, do not adrocnte their introduction at the expense of reducing any other arm, but an of opinion that they ghould be brought in in aldition to the other arms.

I will now conclude by reading an extract from the official report bs the District Inspector of Mrusketry on some Machine-gun Field Iiring which has recently taken place at Aldershot. 'The first extract is from a report on the mounted competition at the Army Rile Bleeting, and is as follows :-

"In the mounted competition of this meeting a section of four men were required to ride orer a course of about 800 yards orer four fences, three men being required to dismount at points 600 and 400 jards from the target and fire four rounds, and ench section was allowed seren minutes to complete tho course. As the cavalry Nordenfelt machine-gan has three barrels, and the gun is served by three men, it was thought that by putting the gans over the same coarso as the mounted sections an interesting and useful comparison could be made between the tro descriptions of fre.

"The best mounted section recorded 21 hits on tho target out of 24 rounds fired. The best machine-gun recorded 3 hits out of 80 rounds fircd.

"The cavalry gans were fired from galloping carriages without removing the horses. The very bad results are attributable to the movement of tho horses, and prove very decidedly that so long as horses are attached to the gun, effectire fire cannot be produced.

- "The infautry machine-guns were put over much the samo course and allowed the same time; the result of their practico was very good, viz., 49 hits out of 80 rounds; in their case the mule was detached from the gun when bronght into action.

"The cavalry gun-carriage is provided with a centre pole and the infantry $g$ an with shafts which rest on the ground when the mulo is removed, acting as a trail to stcady the gun."

I think this report fully bears out mig opinion of the cavalry galloping carriage. If the infantry had only to unhook the trail from the limber instead of unhooking the mule they would have had much moro time for firing, and therefore made still better practice.

I will now read an extract from a letter from Colonel Ward Bennitt, commanding tho. 5th Lancers at Aldershot, to which regiment a s-barrelled gun on a galloping carriago has been for some timo attached. He says: "I disapprove of machine-guns being attached to cavalry regiments, for a Commanding Officer has quite enough to do to look after 100 men and horses when manourring in tho ficld without the extra responsibility of tho machine-gun." Then again ho adds, "to fre a gun with panting horses attached is an absurdity, so that a proper carriage is essential, and the present two-wheeled one is useless." Hero agnin I think my views aro supported.

Colonel the Hov. R. A. T. TALnor, C.B. (1st Lifo Guards) : I hare becn aslied by Colonel Iiddell, who until a few weeks ago was in command of the 10th Fiussars, to read a paper which he has written upon this question.

The Cinsirsas: I am afruid I must tell jou that the Council of the Institution 
do not think it desirable that papers from absent members should be read as con. tributions to a discussion. I'ic idea is, that at any discussion the person who makes a statement slall be present, to gire any erplanation of thal statement, and to receire the reply which it clicits. If, howerer, there is anjthing in the paper which you can state from your own knowledge, we shall be most lappy to hear it.

Colonel 'IArBor : I am rery sorry I was not aware of that rule, or I should haro prepared myself to hare nore perfectly giren the riens of Colonel Liddell upon the subject. It is probably well known that the only real and exlaustire trial of machine-guns that has taken place with caralry is duo to the exertions of Colonel Liddell, a gun haring been attached to the 10th IIUssars for the last two scars. It is owing to those experiments that many inprorements hare been unade in the present gun-carriagc, and in rarious mattcrs connected with tho gun, which could not hare been effected without a practical trial. I will endearour, as bricts as I can, to giro my rierss (which are mainly in accordance with those of Colonel Ijiddell) as to the lecture giren to-day, confuning my remarks chicds to the uso of these guns with caralry, because I think there aro many Ofiecrs prescnt moro competent than I am to discuss their usc with otlucr branclies of the Serrice. I there. fore turn at once to the remarks the lecturer has made as to the use of the gun with caralrs. He sass first of all: "It is intended to be fired withont unhooking the horses, by two men on the limber." Now, I think that is not altogether an accurate statement. It is not intended almays to firo rithout unhooking the horses from the limber, but on occasions it might be so. Where there was time, undoubtedly the horses would be unbooked from the carriage, with the object of putting them umler shelter, and also that the gun might not bo affected by auy morement on the part of the horses, although the disndrantige of such movement had been very much wodified by the prop which MIr. Nordenfelt had adued, which made the carriage almost steady, eren if the horses were not motionless. I therefore think it ought to be considered that as a rule the horses would be unbooked from the gun. The first objection taken by the author to the tro-irhecled carriuge is, "That sufficient ammunition cannot be carricd, probably not more than 2,000 rounds at the outside, which would not last more than eix or seren miutes in rapid firing." In the first place, I do not sec that it nced be put at 2,000 , because I can sce no objection at all to liaring a subsidiary carriage for carrying the ammunition, and as much as 10,000 or 15,000 rounds might be fo carricd. But if it rere so, 1 think there can be no dispute as to the cnormous importance of being able to bring a rers heary fire to bear for sir or seren minutes, eren if it could not be prolongel. . I hare alreads touched upon the second objection, that "The motion of the horses would inpair the accursey of the tire," because, as I hise said, the liorscs mould not be us a rule attaclied to the gun when firing. The third objec. tion raised is, that "Supposing the horse was hit, the gun would be put out of action till the horse was extricated." "That also is met by tho fact that the horse would probably not be in the carriage. Of coursc under erers circumstance accidents mas happen, eren in field batterics, but if onls oue horse is hit and you here your otler horse sound, he would be quite competent to take the carriage out of fire. Therc would also be the corporal's horse, no doubt provided with traces. Probabls the regiment would not bo rerg far off, and would be ablo to provide a trace horse or horses (with lasso equipment), and so jou could take the gun sway almost as quickly as if it had its complete tcam of liorscs. The fourth objection is, "The gun cannot bedetached from the limber to be run up into a position." I cannot see the force of that objection at ull. Tro os three men can readily more one of thasc light guns, but the horses before they were detached, inaturally would take it up to the position, and then if it ras only a question of a few yards, the men could casily push it into its proper plece. The fourth and fifth objections depend rers much upon the lightness and mobility of gun and carriage, and witl a light gun on a two-wheeled carriage almost disappear. The fifth objection is, "The difficulty in getting corer for the gun thus mounted, when it is used in defence of positions." I think the lecturer answers that himself by the later part of the paragraph, in which he enys : "The extra licight would cnablo it to firo orer a higher parapet, which would gire more corer to the men." Mr opinion about this gun is, that its most coocntial feature is its mobility, and angthing that sacrifices or impairs that quality

3 s 2 
reduccs by eo much the efficicocy of tho gun. I attribute greater ralue to mobility. than to weight of fire, or ercn to extrume accuracy. . The great thing is, that it should be able to becp up with caralry, to go forward nnd take up its position, or to retire from that position with the same rapidity with which it took it up. Although I do not wish to go into the technical matter as to which particulas pattern of gun is desirable, I think this featuro ought to be borne in mind, that lightness of gun and carriage is one essential qualification. In a later part of the lecture, Iieutenant Benson saja: "Imagine a caralry rerimeut scut of on reconnoitring duty orer rery rough country, which, though passable for horses, was so in a much less degree for whecled carriages." .From what I hare ecen of machineguns there are rery few places indeed which the gun could not go orer, and I think that objection is really not a rers ralid one. We all knor the marrellous manner in which horsc artillery guns are able to go orer the country, and of course from their lightness and handiness, being between tro whccls onl5, machine-guns would be cnabled to go orer places where ccrtainly horse artillery guns could not go. The Iceturer has fo rery fully gone into the ririous occasions upon which this gun could be most uscfully emplojed, that I do not propose to go into that part of the question. I think his remarks are vers exhaustire on this point. It is almost impossible to orerrate the cnormous inportance of the position which these guns may take in future actions where caralry are cngaged, and my opiuion is, that their part is with caralry more perhaps than with infantry or artillery; although with the latter the necessity of a caralry or infantry cscort would often be obriated. I may say this, that I think in the case of infontry attack, machine-guns would be of rery little use, but where caralsy is attaching, tliey might be of use. But with all arms, for corcring retreats, and for protecting inuportant positions, such 23 bridges, temporary entrenchments, and for detached dutics, I think the ralue of these new weapons can hardly be orerrated. There is, howerer, one point on which I must rather differ from the lecturer, and that is wherc le adrocates the formation of these guns into troops. Those who heard what the Adjutant-General said thi3 year as to the grcat difficulty he had in getting the War Oflice to sanction increased expenditure, eren in matters of paramount importance, will sec that that is a rery considerable dramback to the idea of forming batteries or troops of these guns; but by attaching one or two, or more guns to cach caralry regiment, there would be abso. lutely, in times of peace, no additional expense, ereept that of the gun itself. That point elould be taken into consideration, whether it would be ercr possible to induce the Wro Ofice to establish what rould be practically a new branch of the Scrrice, with its attendant expenditure; but thero would not be the same objection to allowing guns to be attached to each regiment. On actire ecrrice these machineguns would of courso bo at the disposition of the Corps or Dirisional Commander for employment in any may that might be thought proper.

Mrajor WW. WV. MI. Surtm, R.A.: Jíy only title for speaking on this subject is thisI hare not bad actual experience with machine-guns, as the lecturer has dore, in the battleficld, but it is a subject to which I hare giren a great deal of consideration, and it so happened that last summer, when a great many miles amay from here, about the eame time that I supposc the lectures was jreparing his address, I was engaged in kriting a paper of wy own upon this rery subject. I regret that the Council of the Institution hare, as I understand, felt it right that this particular discussion should now be draming to a close. They hate undoubtedly nasigned a great many dajs during this and previous years to the subject, but it would appear to mo probablo that among the manj useful purposes which the Institution serres, a thorough discussion of problents of this kind, particularly when thes are approacbing an immediate solution, is perhaps the most urgent of all its duties; and therefore I think, until the subject has been probed to the bottom, it is rery desirable that the controrersy should still proced, whether. in the printed pames of the Journal, or in this theatrc. I am rery plensed to sce, haring cramined the question, $\grave{a}$ priori, from an altogether independent point of riew, that ny conclusions are almost exactly identical on the more important points with those which Lieutenant Benson from his fuller and riper experience has been able to form. There are, howerer, onc or tro matters on which I am entirely at issue with bim. In the first place I inagine his rien is, that the future "batterics" or "troops" 
are to be dirisional units, just like the threc batteries of dirisionsl artillers at the present moment. Of course there is it great deal to bo said for thint ricw, if it is only as a protest agianst the riew adrocated by M[ajor Anderson and others, that machine-guns ought to be regarded as an integral part of a battalion of infantrs, eren to the csteni of posting them to indivilual companics. I think the lecturer's suggestion a good onc, but that it las gone too far. In the future organization of the new arm (for it is little less), I beliere there aro a Scylla and a Charybdis to aroid; and if the Scyllat is the attaching of a separate machine-gun to cach company, the Clarybilis is surely the attaching of scparate units to the Dirision. In my opinion the machinc-gun ought to act with the brigade of infantry. I differ entirely from the last spenker in his view, as I understood it, that the use of Inachine. guns is more strietly thut of an ausiliary to the caralry than to any other arm of tho Serrice. I beliere that thes are moro suitable to iufantry; and that the better ylan would be to put a certain number of these "troops" or "batteries" under the inmediate orlers of the Jrigadicr commanding the infantrs brigade. The immediale support of the infantry is the most urgent of all the wants of our present tactical srstem. 'The infintes is the arm of the surrice which is told off to carrs an eneny's position or to defend one of its own; and the more closely our new organi. zation subordinates the action of the new weapon to the urgerit necessity of supporting the infantry in both the attack and the defence, the more useful and striking result we sliall get. I am a little bit at issue with the lecturer as to machinc-guns in the new organization being emploged in adlition to the other arms. I agree with the last speaker that we do not suffieiently realize the limiting conditions which are biuding upon us witle regard to the suggestions that we have to make, one of the most rigid of those being that we aro not to propose ansthing which inrolves any rery dargo a mount of cxpenditure witbout indicating sitch financial compensations as would result from its adoption. Now, if ercry Unecr who lins aus important innoration to propose, were to culcarour to show how its uloption would leal to cconomy in other directions, and how br it s nesns certain other arms of the Serrice mighit be reduced within certain limits we should obtain, I beliere, more certain and practical results. If we cuplojed a certain number of machine-gun batteries with brigades or Division, I think it would not bo a rery difficult matter to show that a certain portion of the other arms might safely bo reduced, and to such an extent, I firmly beliere, as to show a rery distinct cconomy, combined with as narked increase of efficiency. Next, with regard to tho weight of the gun, and the number of horses, I think the lecturer has mado possibly tbis mistake. He starts with the assumption, which is no donbt correct, that the ten. barrelled Nordenfelt is a very much moro eficient weapon than the threo or fireburrelled, and therefore that our future insehine-gun is to approsimato in power and weight to this standard, with tho consequent deduction that with the tenbarrelled Nordenfelt, four horses will be required to draw it. I think that in doing this he has conceded a rery great adrantage to the cnemies of machinc-guns, but if he coulh draw up an equipment which will only require one pair of licrses to each weapon, the gain would be very great indeed, and would go a long way towards conciliating thoso who are opposed to its introduction. I beliere such a design to be perfectls practicable. I think it is quito possible to bare a rers cffecicnt weapon on a four-whecled trail and limber carriage drawn by two horses, weighing between 16 and $17 \mathrm{cmt}$, inclusirc of the weight of two or three gunners, and capable of being mancurred at a gallop. If you can achiere that it scems to me that the gun, in a tactical point of view, will be nearly perfect. The target which a two-horso four-wheeled carrioge would present to the enemy's fire would be very much smaller than that which would be presented by the four-horse carriage whith tho lecturer has adrocated. I think we ought to miko the tacticul desidenita tho real basis of our future organization. The weight of our guns must be the consideration which govems all others, and therefore, if the lecturer had commeneed with tho future tactics of the new arsu, and morked out, $\dot{a}$ priori, from that etand-point a suitable weight and number of hosses, he would hare arrired at a result which would bare giren us a more certain eficiency, and rould liare commended itself more fully to the minds of this audience, while making no estraragaut demand on the adaptise power of the inrentors. I will just encetion the results that $I$ havo 
arrired at. I estimate that for a nine machine-gun battery we should require something like 75 to 80 horses and $130 \mathrm{men}$. That is rers much more econonical than the sclieme drawn up by Lieutenant Benson for the same number of guns, which would employ something like 130 to 140 borses.

Licutcuant Bexsox: It is screnty horses for a four-gun batters.

Major Surrn: Mine is a nine-gun batters, and requires from 75 to 80 lorses. and 130 men. With all that I.icutemant Benson has said as to the raluc of the arm, or with the grcater part, I most cordially agrce. He spoke about the enormous raluo which the inachinc-gun rould hare, if suddenly brought, up at tho critical moment, but I think lie had rather in riew that if tho infantry suddenly failed or met some unforescen cmergency, the unachine-guns would covie up to it support. I go a step beyoud that and think that, cren when the infantry which is engaged in the attack of a position is not imuediutely assitiled, when the supremo critical moment of the engagement tales place, when it is a question of moments whether the attacking or the defending infantry is to retire, that is the very tine when, under corer of the smoke, nochine-guns mas gallop up, place themselves, if necesiary, eren in the miclst of the shooting alignments nud renter most orerwhelning moral and material aid. I trust that the paper will gire the coup de grace to ecrtain proposals which hare been previously discusscd in this theatre, one of those being the iden of afliliating the new arm to anj one of the existing arms. I beliere thint to be the greatcst of all crrors, and for that reison I rather deprecate the lecturer's proposal that a nuchine-gun batters should temporarily, for experimentul purposes, be assigned to tlic oflicers and men of onc of the existing 0 -pr, four-gun batterics of artillers. The ofiecrs and men of ny orn corps, rers much as I value their military qualities, after all hare regimental traditions of their own like others hare, and eren if their tactics are not inlluenced by traditions, I think the experiments would to a certain extent be discredited by the mere fact that artillersmen conducted them esclusircig. The way to initinte the experiment with the new arm would, I submit, be to form an altogether new School of the arm at Aldcsshot or clscwlicre, witl represcntatires of every cxisting arm in the Serrice on its list, and prorided with a certain number of wesipons and horscs, and then to let them work the thing out from a totally independent stand. point. Such a school would be a nucleus from which the future corps of machineguns could be formed.

Captain Stose, R.A. : I lare rery few remarks to offer, but thes will rat her bear upon what tho last speaker has said with regard to the mistake which has previously been made- of conrse, 1 speals under correction- of at tempting toaviliate the machinegun to ang particular branch of the Service. I agree with Lieutenant Benson as to tho objections against mounting machinc. guns und ammunition on mules ; in fact, these objections have been already made sumciently clear in the äiscussion whieh followed Major Auderson's paper. I think the systen suggested by Capinin Armit. and others is equally open to objection, and $I$ am sure that the idca of attaching them to the cavalry is opposed by many who have considered the question. If beliere that the feeling at Aldershot, in the caralrs, is rery much against the gun bein: attached to that branch of the Service. I cordially agree with Lieutenant Benson in his suggestion that machine-guns should be mounted on a light guncarriage with a trail, in orler to get tho maximum mobility and stealiness, and I hope to strengthen his position by the remarks thut I hare to offer. 'labing licutenant Benson's organization of a troop of four Nordenfelt guns with small-arm nmmunition carts, wo hare fifty men and sist5-two hores-a somewlint large number. IIowerer, il will bo sufticient for my purpose if I consider a single ten-barrelled Nordenfelt, mounted on a field-carriage carrying three men on the limber-boxes and 5,000 rounds of ammunition, and drawn by four horscs, with a drirer on each of the near horses, and one non-commissioned officer in charge (mounled), the gun being crpable of delivering its fire at the mate of 1,000 rounds a minute. I hope to show that it would be far more economical to introduce troops of machinc-guns, as Licutenant Benson proposes, than cren he imagines. The nerrest machine-gun, known as tho 3Inxim Automatic gun, which has been so cagerls taken up on the Continenl, and with which we are, I beliere, experimenting, whilo other nations are arming themsclres, is a onc-barrelled gun weighing $50 \mathrm{lbs}$, in which the recoil of 
the barrel dlocs the shole of the rork which is performed by hand in other nanchireguns. It consequently requires only one man to manipulate it. The gun is mounted on a carriage with sted plate wheels and a rertical steel shield, the whecls being morable on a pirot, so that when in action they gire, in conjunction with tho shield, perfect corer to the man working the gun. The gun thus mounted can be wheeled alon: by two men, or, if attached to 3 limber containing 5,000 rounds of ammunition, can bo manceurred at a gallop by two horses with one drirer on tho near horso and two men on the limber-boses. Then we come to the question of mobility, and, in order to haro perfect mobility, that is to saj, to be able to more at a gallop, you must hare, so far as I can sce, two horses, with tho iriver on the near borse, and to be able to manceurre the gun just in the same way as with horse artillery. In working this out I find the following comparisons. A gun thus mounted, if attached to a limber containing 5,000 rounds of ammunition, which is the eame amount giren by Lieulenant Benson for his liwber, can be mancrurred by tro horses and one drirer on the near horse, and two wen on the limber-borce. One of these men uright bo a non-commissioned oflicer; but that is a watter of detail. The gun only requiring one nian to fire it, one man is really sufticient, but two men, a non-commissioned offecr and a gunner, would be more than sufficient for all purposes. The gun fires from its one barrel 600 shots a minute, and can continue for any Iength of time without heating. Wo hare, therefore, the following comparison:-ivith the Jaxin gun, i.e., without the ammunition cart (which will be the same in cither case) tho gun and limber, two horses, two gunners (one beiner a non-commissioned officer) and one drirer, as against the Fordenfelt sjstem which, according to Licutenant Benson's propositions, has fire horses, four men (including a non-commissioucd oflicer), and tro drivers.

Lieutenatut Bexsox: What is the total weight of the limber?

Captain Sroxe : I forget exactly. Curiously enough, I find that Jr. Jraxim is sitting nest to unc, and he will be able to give you that. I bare worked it ont, and I find it is considerably less than two horses haro been in the habit of drawing as their share of the weiglit in a field or loose artillery gua-carriage; so that I think I am justificd in my conclusions. The amount of ammunition carried is tlic same, but the Nordenfelt fires 1,000 rounds in a miute from its ten barrels as against the 600 rounds from the one barrel of the Jarim. Notr, without going into the catire personnel of a machine-gun troop, but taking ouly tho strength of each subdirision -not taking the amnunition cart-and inultiplsing it by the number of subdirisions, let us compare a troop of sir Masims and a battery of four Nordenfelts. I find that for the Nordenfelt troop wo haro 20 horses, 16 men, 8 drivers, 4,000 rounds per minute, and 20,000 rounds carrich on the limber. . With the Jinxinu we should have 12 horses, 12 men, 6 drirers, 3,600 rounds per minute, and 30,000 rounds carried on the limber-at rers muel larger number of rounds carried, a difference only of 100 rounds that jou have to delirer in a ninute, which, I think, is unimportant, and 2 saving of rery nearly balf tho horscs-12 as against 20,12 mcn as against 16 , and C drirers as against 8. Iut periaps tho most important point of all is the rery much larger amount of ammunition that would becarricd with the smaller number of liorses, owing, of coursc, to the sery much greater lightness of the gun. I think this striking comparison of figures will much simplify Licutenant Benson's schemo for organizing the macline-guns into troops as soon as we are in possession of a sufficient number of Maxim guns to make the experiment, as it appears to me that two of the principal diflicultics which haro confrouted us hitherto cun bo swept aside, riz., the apparently disproportionate amount of transport required for the results achiered, and the great cost of organizing such transport. 'There is ovio technical point rlich I should like to eco scttled, and that is the difficulty of getting the range by trial shots on certain natures of ground. In the Mraxim gun this can be done approximatels b5 a cleser sighting iurentiou; the sight consists of a pair of calipers so adjusted that when the object (say n man) is, so to speak, risually gripped, by lessening or increasing the interral between the calipers according 23 the range is less or greater, the cleration neceszary for that range is giren nechanically by an arrangement worked on a curre representing the trajectory of the gun, and set in motion by the screw which mores the calipers. So that the rery fact of gripping jour object gires the necessary eleration to the gun. With regard to the crror, i 
hare worked that out most carefully, and, as Lientenant Benson sajs, the most uscful range for the wacline-gun wolld be a sort of link betirecn the artillers and the infantry; that is to 235 , between 1,000 and 1,500 yards. I find the crror between the 1,000 and the 1,100 jards-a difference of 6 inches in the estimated heiglit of the object-would only lead to an crror of 20 sards in the range. At a range of from 1,100 10 1,500 yarls an crror of 7 inches in the cstimated height of the object will give esactly the same error in the range-that is, 20 yards.

The Cusinvax: Witl regard to the calculation of meights which jou hare giren, and which is rather important, do you derire it from a comparison with other carriages, or from mlat the horses can draw?

Captain Stoxe: It was derived from a comparison of the weight of the horse artillers and the light field artillery gun-carriage with limbers all ready for service, full of shell, with the men equipped in marching order, and drawn by six hores. I took one-third of that weight as being pernissible for a pair of horscs.

The Ciraluss: : Did you take into consideration the necessity of the caso that there are four whecls with a certain bulk of material necessary to enable it to with. stand slsock in going orcr ground? Whe method you have indicated seems to we so rers likely to lead to disappointment in the end, that I mentiou it, because there are certain necessities of carriage which hare to be considered.

Captain Sroxe: I hare taken it as less than one-third of the reight of the ordinars Scrricc carriage.' In conclusion, I may say I think Licutenant Benson's suggestion to work the machine-guns as a separate arm is the first practical step in the solution of an obstinate problem, nud, if not trespassing too much on his pre. scrres, I mould renture to add that the Officers shonld be specialls selected from caralry, artillery, and infantry, as well as from the Staff, in order that the raricd requirements of the machine-gun troop may be intelligently met and its action in no way hampered br a too narrow appreciation of the tactical issucs at stake.

Lord ChreysFond: IBcing the only militury nember belonging to the Cuuncil present, I sliould not like to allow this lecture and discussion to pass without sasing ifew words. I think that the Council has reason to congratulate itsclf upon the lecture which has been delirered to-das, aud I am quite sure we all fecl rery much indebted to Ijieutenant Benson for the rers able manner in which he has dealt with this rerg important point. The way in which the adrocate of the caralry und the adrocate of the infantry hare both unaintained that the weapon shouid be attached to their respective arms is, I think, a rers strong argument in farour of Licutcuant Benson's idca that it should not be attached to cither. I must say, speaking as a General Offecr, that I think there would be a rers grcat adrantage in liaving this amm as a special unit attached cither to a brigade or a Division, equipped and organized so as to be used to the best possible uldrantage, wherever tho General Olicer may think best. No doubt at times, I quite admit, the earalry may require a weapon of this description, when it might do right good exrice. Iheutenant licuson forcibly points out the disadrantuge of the weapon bciug attached permanently to anj of the three armz, as cxecpt on particular oceasions it would liamper instead of assist them. When not attached to my particular arm, the General Ofticer could beep these weipons in reserre, and would be able to use them in the

1 On referring to the calculations which I made for the purpose of making the abore comparisons, I find that I have really understated the case for the Jlusim gun.

Tuking the weight which six horses can clrar, at a gallop, as 37 cwt. (wreight behind team in 12-pr. gun), we hare about 12 cwt. as the proportion for cach pair of horscs.

Wcight of Misim gun and carriage $\quad . \quad \ldots 1 \frac{1}{2} \mathrm{cwt}$.

1,336 cartridges in four bores on gun-carriage .. 1 1 , These weights are

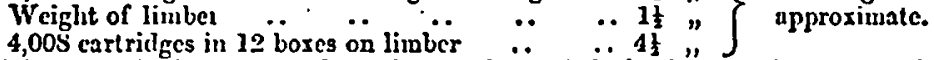

Giring a total of 5,314 rourds, and a wcigbt bchind the horses of 9 cst. or threc. fourths of the share of work which falls to cach pair of horses in a gun-team. I think the margin is sufficient to meet the Chairman's interpolation. The wheels are of hickors; the axle and truil of tubular etcel. 
manner best suited to assist his general plan of operations. Tieutcnant Benson has been obliged to usc the word "Nordenfelt gun," becinusc it is the one which he himeclf has seen in work. I trust that this will not lead to a discassion upon the relatire merits of these guns. We are met here to discuss the broad question as to their organization and their use in the ficll, and it would be, I t!link, vers injurious to the interests of the discussion if we were to diverge into the relatise unerits of mischine-guns. 'There is one point which it is decidedly right slould be discussed, and that is whether a hears machine-gun has an adrantage over a light one, and also with regard to its equipment. I think mysclf that Lieutenunt Benson makes out a strong case for the heary gun, becanse it can be taken at specl orer much rougher ground than the lighter one, with less risk of being upset, and with Ics3 chance of injurs to the weapon itself. With reg:urd to the orginization, I contend that it ought to be a separate unit. Of course, as one of the epeakers has already remarked, there is tho question of expensc, but let us ariue the matter merely from the abstract point of riew, and let us belicro that the War Office will be sufficiently patriotic to gire us the best possible organization, provided we can prore that it really is the most efficicut. Then with renard to the tactics, I do not think there is ang necessits to discuss the use of the machine-gun in the defence of a position or of a fortified post. Tliat is perfectly well established. But witl regard to attack and how machine-gunz are to bo used, no doubt rery important points are raiscd. The infantry now-a-days, with far-resching and precise rilles opposed to them, latre a rerg difficult task indeed when thes hare to adrance and attack a position, und any assistance they wight reccire during that adrance would no dionbt be of enormous ralue. I do not tec any reason why that assistanco sluuld not be giren by unchine-guns, although they are not attached absolutels to the infatrs, quite as, if not more cIectively than, bs the artillery. The artillery take up a position at a considlerable range, uud haring obtained tlat range are able to pour their fire into the cucus's lins, and the machinegun cun be employed in the sane way. But thero is one importuat adrantage which the macline-guns liare orer the artillers at ono particulis period of the attack, which has not been touched upon by tho lecturer. When the infuntrs get within about 800 yarls of the enemy's line, tho artillers cannut assist them any longer mithout firing orer their heads. Now I beliere it has been perfectly well establislied by all writers on tactics that there is nothing that shakes infantry more than the fact that their own artillers are firing orer their heads. It is a vers disagreeable censation; fuzes will not always burst the shell at the right. moment, and any shell coming amongst infantry from thcir own sido docs more to shako their steadiness at the critical moment than any fire from the cnemy. That disadrantage, howercr, docs not apply to machine-guns. Supposing you can place your machineguns in position at 1,200 yards from the enemy, having a good command, the bullets tlat go orer the heads of your attacking infantry would not be distinguished from those coming from the cnemy's sile, and therefore the infantry would get efficient support without ang disturbing influcnecs. In such a case I think the machine-guns could give infantry most important support at a time when artillers would be quite unable to do so, without perhaps doing nore harm than good. I would renture, in conclusion, to say that $I$ beliere artillery in position wight often receive rery cffectire assistince from machine-guns. Artillery hare often to take up cxposed positions to protect the dauk of infantry adrancing to tho attack; they ure consequently often exposed to attack from carialrs, or cren from infuntrs. JLachiuc.guns, tcmporarily attached to batteries so cmplojed, might enable them to remaiu iu action, and prercut them from being serecely liandled by a counter-attack. Such service would be certainly very mucli appreciated by that arm, and would add nuch to its eflicienc5.

Mr. Ilixis: I fully agree with the author in what he has said about the dificults of accurate firing of machinc-guns from "galloping carriages." You can make moderately good slooting from the back of a loorse, prorided the rille is perfectly free, but if the rille and the liorse were fairly sceured together, and the relative position of rifle to horse were regulated by serews and gearing, it would be crcecdingly difficult to make good shooting. So with a gun mounted ou a platform, ono end supported by whecls and the other by a frantic horse, I can conceire it 
would be an excecdingly dificult matter for $n$ man to shoot well with the gun firmly serewed down to its platform as it must be if it is operated by hand. If a gun is operated by hand it necessarily requires some considerable force to operite it; it, therefore, cannot be frec to turn in crery direction, as it would participate in the action of the handle. It has to be ecrewed down to eomething and ained with gearing; in order for the gun to be pointed screws must be turned, and it mould, therefore, be excecdingly hard to do any kind of shiooting from a platforn. which is constantly moring, the relation between the platform and the gun haring to be constantly changed to counteract the morements of the horse. The wachine-gun which I hare made, and which has had manj compctitire trials, weighs but 50 lbs., and does not eren require screws or trainirg-gear. Some speakers hare referred to tho ncecsity of a heary mounting. I nay sas that the nutomatic gun being sclf-contained, requiring no external power to operate it, has very litlle tendency to more while firing. A man can lie down on the gromend and fire it in the same mannes that he cin firo a rifle. He can hare a bos containing sereml bundred rounds of ammunition beside the gun, and by once pulling the trigger he can fire the cntiro box without any mounting at all. There being ouly one barrel there can $b=$ but one shot fired at the same time; the strin is, therefore, very light, and a rery light carriage can be used, and absolutely without training-ncar, cxcept yout wish to fire at $a$ target at $a$ long range. I find that the gun being light and requiring an exceedingly light mounting, I can afford to usc nelicld, the weight of the shield attached abore the gun being about $60 \mathrm{lbs}$. IIs two shields combined weigh less than $100 \mathrm{lbs}$, and this carriage with both shiclds wcighs no more than 200 lbs., so that onc is able to carry into action 1,300 rounds of cartridges attnched to the carriage itself. I find that the weight of the cartridges am the shiclds steadies the gun and enables one to do most extruordinary shooting. For example, in Franco the weight of the cartuidges nnd shicld togethes so steadied tho gun that 80 per cent. of the shots went into a target 2 feet square at 800 mettres, abd the French Officers said at the time they were unable to account for the extriordiuny accuracy of fire. If any of jou nould like to sce this excectingly light curringe I would say that I beliere both it and the gun are on the premises.

Licutenant-Coloncl $\mathbf{A}$.T: The paper we hare heard read is, I consider, an excellent and cxliaustive one; but $I$ cannot concur in the conclusions the lecturer arrives at. Being au artillers Officer he naturally thinks on horseback, and considers that inachine-guns ure not capable of being rookcl with adrantagc by infantry, but should be mounted on horse carriages orgauized in troops of four guns cach, und bo attached to cach division of an army corps. IIe gires his reasons anginst their use by iufantry under three heads, to which I propose brienly to reply. With reg:trd to the enormous labour of dragging these guns in a canjpaign, I can only point to what the men of my own linttalien hare done regularly witl the Euster marching column, and at the Aldersliot drills, for sercral years past. The 5-barrel Nordenfelt guns mounted on our magazine carringe hare been dragged from Petersfield to Portsmonth, from Canterbury to Dorer, from East Grinstead to Brighton, from Aldershot to Pirbright, and back ou a bec-lino across the Fox IIills, and the Long Valley, with its ruts and dust, is as faniliar to our gun detacliments as Oxford strect to a London cab-driver; no high-roals, byc-roads, country paths, hills, or downs encountered on the was, hare checked their march. Our men nerer complain, creept at the indignity of it being proposed to relieve them, and only accept assistance when breasting a slippers slope, impract icable for artillers, or a stecp incline on a heary or nerily-nictalled country road. Any loss of distance under such circum. etances is more than picked up at the double on the down grasle, and bj the time the baltafion is in attuck formation the guns are almogs in position to take part in the fighting line. If we can do this in the Folunteer Scrrice, Tomms Athins is not the man I take hin to be if ho mutinics against being called upon for similar work in the regular Serrice. With regard to amwunition, our magazine carries 5,000 rounds, and cach man of the gun detachment 100 rounds, nsiking 6,000 rounds arailable for each gun the moment it comes into action. The replenishment of this supply in netion is a simple matter of detail. Witl regard to band draught giring the least possible mobility, I hare already shown that our guns keep up with the battalion under all circumstances, which is all that should be required of 
them ; but if additional proof wero wanting of their mobility, I may mention tiat one of the guns, with the usual detacluwent, has occupied a bridge two miles to its front, and come into action in nincteen minutes; and for getting across didicult country. for a similar distance, I would like to buck onc of my hand-drawn carriages against one of Lieutenant Benson's horsed nagons with limber. What I mean is going straight across country bJ-paths, fields, over banks, ditches, hedges, unything that came in the way. I claim for the hand-dram gun all the adrantages of machine-guns so ably pointed out by the lecturer, mith tho alditional adrantage: that they form a unuch emaller and more difficult to bo distinguished mark for the cnemy's artillers and infantry than any other system; it being rery hard to distinguish them at any distance, on certain grounds and in the smoke of action, from a cluster of skirmishers. With two guns attached to each battalion a Brigadier or Divisional General could mass his machine-guns if occasion called for it. I do not think that my battalion is reakened by the detailing of the necessary detachments to work the guns, but that confidence is rather imparted to it by baring its lanks corcred by those meapons, and by the gencral fecling of eccurits their presence: imparts to tho rest of the line; and I do not find thes get ans more out of ny control in practice than the companies of a battalion in extended order or cletached for outpost work. I should be pleascd to seo machine-guns attached to each branch of the Service, but I contend that as thes are but elusters of rifles their proper place is with the infanter. I contend also that they should be mounted upon a single magazine-carriage to be dram by hand without being cncumbercl with shafts or scpirate limbers, which are impediments which I found to interfere nltogether with the effectire working of the guns, and which might with reason be complainel of by Tommy $\Delta$ thins, if he tere given machinery of that sort to manipulate. It appears to be the generul feeling of tho meeting that thesc guns should bo horsed and morked in batterics. Ancl with reference to Lord Chelmsford's remarks as to the firing of machine-guns orer tho heads of infuntry not risulting, as with artillery, in shells sometimes dropping upon jour own men, I mas sugest that there are such things as defectire cartridges, which sometimes fall short, as I hare found to bo the caso with ficld-firing experiments at Aldershot, and it would be just as startling to men adrancing across country to find a few bullets coming into their rear as it would be to hare shell bursting short orer their heads. I was glad to hear SLajor Smith ndmit that these mounted guns wight gallop up at a giren moment and take part in the fighting line, but it appears to me that if I can sneak np my machinc-guns mith the fighting line iny non-commissioned oflicer3 or Subalterus aftached to them can judge much better as to the best position to bo occupied than one of these flying batterics, dasling up in the lacat of action to take up a position; and I think my guns mould be much better able to produce the effect which it is desired to denonstrate could be obtained by tho fying battery. Trime prevents wy touching upon statisties with regarl to weights, number of men and horses, de., and I therefore conclude by tentering my personal thanks to the lecturer for his raluable contribution to the subject of macline-guns.

The Cnsinsax : Do I rightly understand you to adrocate machine-guns being galloped up?

Lieutenant-Colonel AIr: No; I say I can get across an ordinary enclosed country on a bec-line as fast, for a milc or a couplo of niles, as a horsed battery of machine-guns rould be able to do by haring to kecp to road or elear array banks and ditclies to get through.

I'he Cramessx: I only interpolated becauso I thought you spote with approral of what Jrajor Smilh eaid as to their being galloped up in front.

Licutenant-Colonel ALr : It has been objected to machine-guns that thes could not take part in the fighting line, but I hare always so worked $\mathrm{my}$ guns when neceseary, both at Easter rerierrs and on field-days at dldershot. I do not consider they would be likcly to suffer more in that way than the indiriclual inen would be which formed the fighting line.

Mr. C. FuEdenick Lore: At the Jecture giren on this subject in January of last Jear, when Lord Charles lieresford was in the chair, I called attention to the fact that General Gordon, in his diars written at KLartoun, in J)ecmber, 18S1, a fer days before his deatl, said, "Against a gool mitrailleuse, and a sharp operator 
with a gond telescopic sight, no gun could be serred with impunity et 2,000 5ards range, although it could be ecrred against artillery fire, for at that rango there is plenty of time to dodge under corer after secing the flash ere the shell arrires." Now I am in a position to say that this rery practical suggestion of Gencral Gorlon is fully endorsed by a distinguished and gallant Oflicer occupsin: a rery high position, and it would be interesting to learn whether the makers of unachine-guus hare taken any practical measures to carty out this idea. Of coursc the theory formed by Generil Gordon ns to the effect of these telescopic sights was founded on the erperience of the Americin Ciril War. Since the date of that lecture I hare been faroured by letters from Onicers and soldiers who took part in that war with telescope rifles which were manufactured in this country, and min thin blockade. The other day I got a letter from a Colonel in the Confolerate Arms, in which he eaicl that wben General Isongstreet's corp3 nas approaching Suffolt, in Yirginia, in the carly part of 1863 , b5 one of the lerel roads leading to that place, the adrance of the corps was discorered by a Federal signaller, perched on a berrel erected on the top of a high pole, like the crow's nest used by the Aretic rojagers, and who was seen eignalling the Confederate unorements to tho Federal troops in his rear. Sereral of the eharpshooters of Longstreet's corpz were armed with Whitworth telescopre-sighted rifles, and one of them being called to the front was told to try a shot at the occupant of the crow's nest. This he did, and the man immediately disappeared belon the edge of the barril, and no more signals were giren by lim. In the advanee then made the Federal shirmishers nero driven back begond the crow's ncst, which was found to contain the dead body of a soldier shot through the upper part of the boty. The great distauce at which he had been killed induced General Longstrect to hare it measured, when it ras found to hare been 1,300 jords. I hare otler letters from other Onieers in the Confederate service, and also from ono of the men who carried one of these rifles through the whole war, piring similar details, and on the other liaus there is a letter from an Oflicer in the Ficderal serrice.

The Charryax : I think this is rather wide of the mark.

Mr. IowE: Then I will renture to draw attention to the fact that the sights of rifles, machine-guns, and cannon areall alike. I venture to say that the sights of all the present fircarms in use are rery defectire. I was told by a gentlenas whose b!tincss it is to make and sell machine-guns, that he once shot-

The Cirsinzess: I um afraid it is not relerant; there are many gentlemen anxious to speak, and our time is extremely short. We hare had ample eridence that the desire of the mecting is that the discussion should be directed to the question of machine-guns.

Mr. Lowe: JIay I suggest the application of the principle of the aperture sight to machine-guns?

The Cuamuas: No. What we hare to deal with is the general question.

Colonel lasbor Coks: I nish to say onc or two words with regarl to what the Iecturer lias said, mamely, that it is during the time of peace that iro should make cxperincnts for war. During the two scars that tlic battalion under my coumand has been at Aldershot, we hare fully tested the machine-yuns, both on ordinary ficld. dajs and in the usual peace manmurres. The first guu we liad was mounted on pack mules, and I quite angre with what has been saiủ, thal it was uscless when so carried. This year we hare the sailor's carrigge (such as is used by the Naral Irigade), drawn by one mule, and that carriage is also rers faulty. I firmly belierc that thero is only one class of carrizge that will crer really incet our military requirements, und that is the limber with the trail. I will not. enter into the subject of weight, but I think it is a mistake to go from one mule to four horses. One mule las hitherto done our work with ammunition und gun on one carriage, and to jump from thai to four lorses is rather too long $a$ step to be taken all at once. I should like to sec the infantry gun with a limber and two horses. As to the concentration of guns in the field, I thirk that might be carricd out by the Brigadicrs, eren if the guns are with the various infantrs battalions, and I quitc agree witl the lecturer, that for practical purposes thes should be concentrated in the field.

Captain Warter Ir. J.1Yes, late R.I. : Laring some jears ago adrocated tho 
question of a carrisgo from which the machine.gun could be fircd without unlimbering, I would ask permission to say one or two mords on that subject. I am perfectly prepared to aclmit thast the idea of a gun firing while retiring is eomewhat of a Utopian character, but if you concede that tho wachine-gun is chicdy a horse artil. lerg werpon, I think there are moments in the collision of lostile caralry when a machine-gun which can be fired, eren though the horse do disturb its aim somewhat, will be of the greatest utility. The only other point to which I would like to draw attention is one which has not jet been alluded to by tho lecturer, and that is tho position that the inachine.gun occupies at the present moment, when a ewall-boro rifle is about to be introduced. The great object sought to be gained by using $a$ cartridge of the same bore as the rifle was that it prerented the introduction of another lind of ammunition in the field, with all its attendant digadrantages. Granted, but when jou come to this, that in a rery short space of time you will find your infuntry armed with a weapon, if $I$ may judge from a recent General Order, of 0.293 calibre, it will be a rers grare question whether for sour machine. guns you will retain the same cartridge, or whether you will not be able to get a much more eflicient weapon by introducing a diffcrent bind of machinc-gun alto. gether. When the French introduced their mitrailleuse they used a much hearier cartridge than that for the rifle, and $I$ do not know that there is any instance in the record of the 1870-71 War of failure of the ammunition supply. Therefore it may be conceded that it is possible to supply your mitrailleuse with whaterer cartridge you determine shall bo emplosed in it. This being the case, we hare to consider what will bo the best cartridge to gire the machine-gun in the future. One difficulty with the machine-gun is undoubtedly range-finding, but Iicutenant Jenson proposes to attaci a gun which shall be used for wo other purpose than range-finding.

lieutenant Brisos : And to be carried on the limber.

Captain Jayes : I will go further. I would propose the introduction of a ueapon which can be uscd for range-fnding and for-figliting purposes in addition. We are all of us arare of the great stride made in rapid-firin: guns of late, and it seems to me that the futuro best form of mitrailleuse will be something of this kind : firing a shell which shall exced the Genera Conrention weight, i.e., orer I lb., probably 2 lbs. or 3 lbs., which shall contain a ligh explosire fired with smokelcss pomder, witl a muzzle relocity of 2,000 feet. You would obtain a rery different cffect from a battery of theso reapons to what could be got from a battery of riflecalibre mitrailleuses; they would not only possess man-killing powcr, but also battering power, becauso eren tha small charge, of say gun-cotton, contained in thoso shells, which mould probably bo of stecl, would hare a fairly cficicnt battering charicter.

The Cinsirax: Would they explode on impact?

Captain Jayrs : Yes, of course, with percussion fuzes. I hare come to this conclusion, therefore, that the new rille cartridge is not adapted to the machine-gun, becauso it is so rery dificult to find out what it is doing; that the adrantages to bo obtained from machine-guns can be rery much better obtained from a quick-firing than froun an ordinary machinc-gun as accepted at the present moment; and then I come to the point ns to bow these batteries are to be organized. I sm distinetly of opinion that the cobbler should stick to his last. If you attach the machine-gun to infantry or to caralry, or to anjbody but themsclrcs, I think they will always occupy a sccondary position. I am conrinced that you ought to organizc jour machine-guus in special batterics. Various propositiong hare been made of this kind. Some ycars ggo a gentleman ras good enough to suggest that they should be attached to the branch of the Serrice to which I belong; but I do not think that is a practical suggestion. I think they should be organized in battcrics, zuch as haro beca suggested by Lieutenant Benson, or as was suggested in this theatro a great many Jears ago, just after a Committee enquired into the use of machine-guns in the field. What should these batteries be attached to? I think they should form special reserres under the Dirisional Commander. I should be almost inclined to go cren higher in European warfnre, and eas the corps Com. monder; that a corps Commander, taking our present Ariny Corps, should haro perhaps trelre of these rapid-firing guns attached as onc batters, and in addition 
to that I think it should form the main weapon of the horse artillers attached to the caralrs. It would take too long for me to go into the special tactical uses of these guus; a hears, rapid, and continuous fire fron such a batters as I suggest rould, I think, be much morc eflicacious than that from any mitrailleuso merely firing the inf:antry bullet of the future.

MIr. Nondr.selt : I wish to be allowed to protest in a gentle way against one remark of Licutenant Benson's, riz., the last remark he made about the firing at sldershot. It is quite true that on one particular dag the guns did not hit well, although on the prerious dass they had done rery well. Major MIecham, the Musketry Instructor at Aldershot, and the Ofticers of the regimert, had trained the men rers perfectly witl dummy cartrilges, but before that trial I beliere thes liad not fired any ball cartridges, except a slatil number on one day preriously. It is necesary for men to bo trained for machine-guns alnost as much as for rifles, and I do not belicre that any man who lias only fired 300 rounds can suddenly set to work and hit targets nt long ranges, indecd Iieutenant Benson admits that himself. The infantry carriage und tho cavalry carriago hare been mado with a rier to mobility. When Lord Charles Beresford came back from Alezandris, he told me that he dia not see why we could not arrange guns to act liko torpedo-boats ashore, and it was entirels duc to Lord Charles Beresford that I commenced to push forward tlicse galloping carriages. Since then Colouel Liddell, Major Wilson, and Captain Baden-Powell have been working for montlis with these carriages, and have gained a grcat deal of expericnec. At Aldershot ths results of target firing hare been sometimes good; and sometimes bat. Amusingly cnough, some of uny own men went down the other das, uul fired rerg badly; in their great anxicts to fire quickly, they did not hit at all, whereas the disciplined men trained bs the three infantry regiments made uncommonly good practice, in some instances at 400 jards making from 80 to 90 per cent. of hits. Although it is not for me to decido in what manner the guns should be emplojed, I hold with the lecturer that the mule can only be used in mountain warfare, but for this purpose I fully believe that the mule will be uscd, because there arc many occasions when a light gun in mountain ferrice will be found to be exceedingls useful; but it will have to be on a separate mourting, in the same was as in the case of other gung for mountain serrice. Fert, ans to the infantry and caralry, whether the gun is to be used as purt of a regiment, or as 2 tactical unit of a brigade or a Dirision, I do not pretend to understand; but guns actually following the regiments or brigades on certain opportunities must be excecdingly useful, and must come into the arnies. The guns will lase in some way to be attached and organized so that the Coloncl and the Brigadier.Commander who needs them will not hare to eend a messenger half a mile to the Dirisional General to ask for them, becausc then thes mas nerer find onc another again. The gun must be excecdingly handy; the opportunitics given for its use may not last more than a winutc or two, and if it tules firc minutes to go and ask for the guns they may lose their chance, which night hare been inraluable. That is the point on which I stronuly urge the ralue of mobility. Mlobility is a relatire term. With an infantry regiment it means the epecd with which the infantry can more at tho double; with caralry or artillery it means the speed at which thej can go; therefore, I belierc that the galloping carriage, with perlaps alterations such as lare been described, or some other carringe, must be used for the machine-gun. Lieutenant Benson has misunderstood one point. He says the horses are not taten out. The idea is that the horses should be taken out at longish ranges, when jou are not under inmediate and close fire, but that the horses should be left in the shafts at short ranges, when you suddenly como upon your enemy at anything between 200 and 800 yards. For that purpose, when your target is not a small target but a large one, I belicre it vill be found on extended practice that the morements of the horses do not scriously affect the gun. I euy this distinctly, because if you take a target repreecnting a squadron of caralr, it will be about $a$ feet high by 50 fect wide, and that target will be hit by a rery large perecntage of shots fired at theso runges, whereas if jou fire at the Wimbledon target with a bullscye, you may not hit it with any Iarge percentage of the bullets fired. The machive-gun is intended to fire a min of bullets falling for a short tine, but the moment rou berin to calculsto mean deflections mcasured in inches, sou may not lare good targets. If you heep before jour 
mind that the machine-gun is not meant for that purpose, except possibly firing at a General and his st:aff at long range, you will nerer usc it for accurate firing, but simply in orler to throw a sudden and unexpected rain of bullets on your cnemr, he not knowing where on enrth thes come from. Captain James spoke about the small-bore cartridge. This cartridge can only affect the machine-gun in the same way us the rifle. If the cartridge is only two-thirds of the weight, that means that you can carrs 30 per cent. more aumunition within the same weight. As to quickfiring guns moring rapidly, I am cntircly of Captsin James's opinion, but it lass nothing to do with rifle-calibre machine-guus at all. Machine-guns are separate things fring rifle cartridges, and I am certain that the machine-gun must be adopted into the Serrice in conuection with caralry and infantrs. I do not eare whether it is a separate tactical unit or attached to regiments, but if elerer gunners like Lieutenant benson can possibly work up an interest in farour of haring heary guns with artillery mounting, I for ono shall hare no objection, but I liaro not very grent hopes of it. 'On the other hand, I fully beliere in the 6- or 8-pr. Shrapnel guns which I am making. Thosc guns, I believe, will and must go whererer light artillery goes, but heary field artillery cannot more quickly enough, and cannot adrance so clnse to an encmy as these quick-firing guns protected by their shiclds are able to do.

Major-General Arnetrwor: I hare had a great deal to do with experimental guns, and all the machine-guns in the Serrice have passed through my hands. Perlaps, therefore, I may be allowed to say a fer words. I am not going to touch so much upon the question of tactics as on that of equipment, but I think that there ought to be two scpurate cquipments, one for caralry and one for infantry. With regard to whether the gun slould be altached to a regiment of infantry or caralry, or whether it should form an independent unit, is I think a matter of minor importance, prorided jou hare a eeparate equiprnent for the two arms with which it is to be used. The galloper carriago first intruduced two jears ago was got up on Lord Charles Beresford's suggestion, and has becn worked out sinco by Colonel Liddell, 3Ir. Nordenfelt, and insself, and I beliere the last carriages which hare been issucd bare giren general satisfaction to tbe lotly IIussars, which regiment has carried through all the experimental work. Although one of the regiments at $A$ dershot nade threo hits out of eeren rounds, the 10th liussars certainly made mueh better practice than that. I hare scen them practising with the guns on the salloper carriages with the horses in the shafts, and ther ceriainly made many anoro hits than tluree out of seren, or whaterer it was. I thiuk if the horscs are traincd and the men are trained nnd understand the working of the guns, with the aid of the prop which has been introduced by MIr. Nordenfelt, very steady firing can be obtained, oren without taking the horses out.

Tho Cicamsis : At what bind of target and at what range?

General Andernxot : At ranges below 600 jards and the horses left in; bejond 600 jards the horses was be taken out, and the: the fire will be just as stcady 88 on any other biud of curringe on which the gun inight bo mounted. 'There is ono great adrantage in the tro-rhecled carringe for caralrs, nomels, that it can bo brought into action pretty quiclly, whereas if jou hare a limber, and jou haso to unlimber your gun beforo you go into action, sou cannot fire half so rapidly as if sou carricd tho ammunition with the gun itsclf. With regard to the infantry mounting, thero are two equipments for infantry, ono being with mules, which is intended for mountainous countries. It is nerer intended that the mule cquipment shall be for the ordinarg serrice of the machine-gun working with infontry, but just as you hare tro equipments for artillers, tho mountain equipment and tho goneral ecpuipment, so with the machinc-gun. Thercfore, to say it is uscless is only to say it is useless if you are in a country where a superior carriage can more, but it.will not bo useless in a hilly country where jou cannot uge the ordinary carriage. The mule equipuent of the machine-gun is a rery good one for the purpose for which it is intended, natrely, for use in mountainous countrics. With regard to the two-whecled equipment of machine-guns to bo used in conjunction with infantry, tho mounting is based on the same lines as the landing carriage for the Navs. That landing carringe for the Nary was got up after the campaign in the Soudan. The Taral Brigade thero had a Gatling equipment conrerted to talo the Gardner gun 
with a limber, but it was found so heary and so inconrenient, and in crery was so objectionable, that Captain Wilson, R.N., who had the working of thcse guns in tha Soudan, wrote a report on the subject, in which report he adrocated the adoption of a two whecled in preference to a limber carriage. A Cummittco was formed, of which Captain Wilson was a member, and which recommended the two-whecled landing carriage which ros subsequently adopted, and which I beliere gires general Eatisfaction in the Nary; it has entirely orercome the objection which was found mith regard to the use of the limber carriage. When it was desired to get up an equipunent for the infantry the naral landing carriagc was taken as the lino on vilich to build the infantry carriagc, in couscquence of its haring prored so succesful. I am speaking under the correction of Mr. Nordenfelt, but I beliere the landing carriage which mas used for the infantry as far as regards the mounting ras on the eame lines as the landing carriage for the Nary.

Mr. Nonuesfelt : Entircl5.

Gencral Aryorixor: That carriage was two-wheeled; two horses can be put in it if necessary, a man riding on the near horse. That is considered preferable to laring one horse and leading it. There is no objection to a man riding and driring the carringe. The gun can be fired with perfect steadiness. The horse can be cither taken out, or the gun can bo fired witl perfect steadiness by propping up the shaft if the horse is left in. I hare seen most excellent practice made with a gun mounted on a carriagc of that sort, and considering that it can carry 2,000 rounds of ammunition that gires it an immense adrantage orer the limber carriage, which should not be forgotten. With regard to the weight of the gun, I think no gun issued to infantry or caralry should exceed 100 lbs. in wcight at the rery outside; ansthing besond that to my mind necessitates a rery much heavice carriage and wants more etrength. A gun under that weight could be carried on a comparatirely light carriage, because there is not the same wear and tear as with a hearier gun. Another advantage is that it carrics very much more ammunition for the samo weight. I do not anree with Captuin Jacies, that the small-borc cartridge is unsuitable for the machine-guns. I think if a cartridge is cficient out of a rille it is equally cilicient out of a machine-gun, and to my mind the great adrantage of the macbine-gun acting with caralry and infantry is that it elould fire the samo ammunition as rilles, because then erers reserre of ammunition rould supply both machine-guns and the rilles.

Captain Jayrs : Jiay I be allowed to explain? I do not denj the use of tho new cartridge with a machinc-gun, but I beliere you will get a rery much better effect, quite worth all the additional complication of ammunition, out of iny proposal.

General duBetixor: That is a point I should hardly touch on to-night. The question of the ammunition of machine guns is somerhat departing from the subject of this discussion; I think, howercr, bcing ablo to carry morc ammunition is anotlicr adrantage of haring the light cartridge. If the gun is, say, 90 lbs. in weight, you can carry 2,500 rounds of ammunition without its bcing too much for onc pair of hor:es, and you can haro a carriage strong enough to carry that weight of ammunition with a light gun. I think the 10 -barrelled Fordenfelt is altogether out of the question for field work. If jou go into that great weight of gun, jou may at once bare ficld artillery, it is altogether bejond the question of musketry, it is too heary a gun for field purposes. There is ono point that has not been touched upon, and that is rith regard to tho uscs of machine-guns. I think it will be found in warfare that they are more useful for defensire purposes than for offensire. For defending a bridge, or a defile, or for strect firing, the machine-gun rill, I think, be inraluable. You can by its means fire a rain of bullets concentrated on one spot, domn a narrow lane, which wo number of men could erer attempt to compete with. I think myself, a largo number of guns of a few barrels cach rould be inore efficient than one gua; with sereral barsels, because the fire can bo epread orer a larger surface. Fou cannot kill a man more than once, and if you firo your 10-barrelled Nordenfelt, ten bullets maj hit one man, which is not tho serrice that is wanted. What is wanted is to spread the firc orer as large a surface as possible with o fer barrels. I will not detain you longer.

Licutenant-Colonel J. P. Brdbizox, 10th Royal IIussars : Sir, I.rise to mako a for obserrations on this important subject, and do so with the greatest diffidence, 
as, unlike most of the speakers whom we hare heard this afternoon, I hare not had the adrantage of reading or knoring the contents of the rery ablo paper by Licutenant Benson, until it was read to us by bim a $\mathrm{fer}$ minutes aro. When I entered this hall I had no intention (as I was utterly unprepared) of taking part in the diocussion, but with jour permission I should like to make a few remarks on what I hare heard fall from the speakers who hare preceled me. As to tho deacription of machine-gun, and its rarious scientific technicalities, I leare to clerererimen than myself to determine, but for ceralrs it is absolutely neccsars that it sliould be of a light and handy description. That attached to wy regiment, and horsed with two horses, has in my opinion prored itself a rery light, hands, and suitable weapon. But one detail I think common-gense points out to us to be absolutely necessary to its utility, and that is that it should bo of the same calibre, and carry the same cartridge as used by our infantry. Lord Chelmsford, in his remarks, eaid that tho grcat anxiety shown by both infantry and caralry to hare this machino-gun attached to them was a reason, in his opinion, that neither should hare it. I beg to differ most entirely with his lordship. Finglish soldiers aro rery conserratire and look rith distrust on any change of armament and equipment, and the rery fact that these two branches of the Service are so anxious to get it is, in my opinion, a strong reason not that neither should hare it, but that both should. When I mentioned two arms of the Serrice I ourht to hare included tho. third, for artillersmen seem as anrious to hare it as an adjunct, as do the infantry and caralry. I have heard during this discussion the machine-gun frequently alluded to $23 \mathrm{a}$ "gun " and talked of as being in "batterg." I protest against this. It is not a gun in the popular military acceptation of the term. It is a "rifl," pur et simple, a machine rille, and a rille that in my opinion ought to be permanently attached to erery caralry regiment, whaterer it 3 best position may bo for the other branches. Mr. Benson I belicre firours, and Lord Chelmsford supported the idea, that thesc machinc.rifles should alkays be attached to the artillers, and in action eome of them placed under tho immediate command of Brigadiers and Generals of Division, to be sent for when मanted; this would in $\mathrm{my}$ opinion nerer answer, especially as far as caralry is concerned. It is essentially a weapon of "opportunits," to be used on the spur of tho moment, and if that cliance is allowed to slip by, the ohole raison d'stre of the gun disappears. Napoleon, when he adranecd on the Danube in 1805, had his caralry from 80 to 100 milcs alead of hiz main body. In the Franco-Prussian War, the German caralry, whenerer possible, was from 20 to 30 miles ahead of the infantry. The róle of caralry is to bo as far as possible in adrance, and act as a screen to the main body. Imaginc caralry not 80 or 100 miles, nor cren 20 or 30 miles alsead, but eay only 4 or 5 miles aluead, and suddenly finding a eplendid opportunity for using these guos, and haring to eeud back niles to get them, it is a thousand to one the opportunity when they might hare been of the utmost utility would hare fled long before thes could come up. I ain surprised, from an extract rcad out of a letter from Coloncl Ward Bcnnitt, to find so distinguished a caralry soldier an opponent to haring this weapon attached to his regiment. I cannot conccire a caralry soldier not receiving it with open arms, for I foresee that their introduction as part of caralry armement will be of immensc serrice, and tend to kccp the caralry soldier whero a caralry soldier ought to bc, viz., in his soddle. Englishenen understand the horso better than any other European nation, I think I mas any better than any other nation in tho world. We brced the best horses, our men ride better, nre better dressed, and better equipped. We hare erergthing in our farour to make our caralrs, if small in number, the most splendid body of horsemen in the world, and we throw all these adrantages to the winds and Forry ourselres with trging to turn what ought to be, and could be, the most magnificent caralry into indifferent infantry; just as on the same principle we are turning our best infantry into erecrable crralry under the name of "mounted infantry." It is lamentablo to me to see the role of caralry so completel 5 misunilerstood, sud I know nothing more ridiculous and heartbreaking than the sight of a diomounted dragoon, encumbered with sword, sabretascle, and spurs, carbine in hand, dodging sbout bushes like a rabbit. I forcsee that thcse guns may possibly sare us from all this, and once more put our splendid caralry in its proper place. But then some people are rery narrow-minded about clanges of anj sort, and I am afraid lancers are

Fi)L. $\mathbf{x \times 1 .}$ 
ultra-conecrrative about their armament, for I remenber there wag just as strenuous an opposition on their part to the introduction of carbines as there now appears to be to the machine-guns. I remember, at the timo I allude to, an Officer of lancers who was about to exchange into a hussar regiment telling me that his old troop ecrgeant-major asked him if the report he heard of his intended exchenge ras true; on being told it was, said sadly: "Well, Sir, of course you know best, but personally I sliouldn't like to bo found drowned in tho eame parish with a carbine regiment." Evidently lo feared that his friends might think he lad passed his last bourz on this carth in tho disrcputable company of anjone who could use a carbine as a weapon of offenco or defence, and apparently tho old conserratire scrgcant-major is not singular, and therc are some of the opinion that ans regiment who can adrance the utility of tho macline-gun must bo as utterly disreputable as the carbine reginent referred to by tho old laneer. Referring to the Germans, the most practical and ecientific soldiers of the day, and their estimate of the machine. gun, I may remind sou that they were opposed in 1870 and 1871 to an cnemy that lad machine-guns (mitraillcuscs) attached to their infantry, but thes apparcntly did so little dimage and rere so littlo thought of by the Gerwans, that though serenteen years clapsed since that war, I hare nerer heard of their adopting machine-guns as adjuncts to their infantrs battalions or artillery batteric3. Last summer, howerer, Prince William of Prussia, accompanicd by some of the most distinguished caralry Ofiecrs of the German Arms, who wero orer here for the Jubilco rejoicing, did my regiment the lonour of paying us a risit at IIounslow, and were so impressed with our tro-horse Nordenfelt gun, its handiness and appliability to caralry morements, and the casc with which it kept up and mauæurred with us during a galloping ficld-daj, that Princo William immediately ordered a facsimile gun to be eent orer to Germany, and we sent orer one of our men to Potsdam, to show them how to work it; and eo taken by it are they, that I belicre I am right in saying that it is going to bc adopted for their caralry. Lord Charles Beresford is anxious for mo to repeat what I told him a few minutes ago as to tho confidence it inspired and the popularity of this gun anong the men of mig regiment. I was much surprised to hear from one of the gentlemen who preceded mo that he found the consensus of opinion among caralry Oflicers at Aldershot to be adrerse to this gun, and that it win unpopular with eoldiers; all I can eay is that such is nol the case in my. regiment, where the gun is rery popular, as I confidently beliero it will in time become with the remainder of our Army. Great stress lias been laid by those whom I may call the opponents to the gun on tlie danger of its bcing put oul of action through horses being shot, or from being upset going orer rough ground. There scems to be much misapprehension about the way these guns are to be used. On only the rarest occusions hare $I$ secn them fired with horges attached, and then nerer against infantry. But there may arise occasions, when you want to get a few rounds in against caralry adrancing in close formation, when it would be nccessary to ueo them with the horses attached, so that they may continue firing till the very last second and then gallop away out of nction or under corer of their onn cirralry. As regards the horses being shot, that is of course an accident that equally obtains with artillery, and a guu with its lead horses shot is equally out of actiou until they are replaced by others. In every troop thero are fire or six liorses trained to harness, and if one or eren both horses were shot thes could bo casily and specdily replaced. As regards their upsetting, they can go anywhere where caralry can go. I hare secn our gun worked orer the For IIIlls (rhich I thint ercrsone will allow is bad ground for caralry; al all erents, I liare nerce seen a ficld-das there without both men and horses going head orer heels, through galloping into the heather-hidden holes and ruts), and yet the gun working at a gallop lias nerer come to grief. But stuppose it dicl. Suppose all tho horses trained to harness were shot. Suppose the gun went head orer hecls, and was 80 damaged as to bccome useless. It would be bad luck, but not an irretrierable disaster. Innock out a linchpin and leare it, $835 \mathrm{I}$. One thing I would not do. I would not sacrifice a single life to sare it, out of pure sentiment. Neither would I sacrifice a single life to sare any gun, out of pure scutiment. I lare often, at Ndershot, had our gun attached to my squadron; hare often asked for it, if sent out to wateh or oppose a superior force, feeling tluc great adrantage which its presence 
must gire me, and haro nerer jet scen a feld.day when I should not hare had an opportunity of using it with extraordinars effect. In conclusion, I may e25ithat it is my firm conriction that a caralrs regiment armed with these guns as they should be, viz., four guns, one to cach squadron, would be moro than a match for any two regiments not similarly armed.

Captain R. S. BaDex-Potrel, 13th ITueserg : After what Colonel Brabazon has said, there is not much left for me to add. In selecting our tools for any lind of work, we usually look to the particular sort of work we are going to do, and if we want to use a sledge-hammer or a tin-tack drirer, we do not go and select a farrier's hammer that will do the work of both-equally badly. Licutenaut Benson has selected a rery nice kind of machine-gun for general purposez, but I do not think ho has fully considered the rery different valure of the work that the rarious arms liare to carry out. I do not think, for instance, that he has noticed the great difference betricen caralry rork and that of the other arms. To ms mind there is as much difference between the action of coralry aud that of other arms as there is between an Englishman's way of fighting and a Frenchman's. The infantry and artillers fight the good old English way; they squarc up to cach other and hare $i$ out hammer and tongs, but caralry figlit moro in the manner of the Frenchman, wlio comes up to jou, looks jou straight in tho face, clenches his teeth, and then suddenly lets you hare a lick on the shing before you expect it: The success of caralry foliting lies in sudden attacks from a most unerpected quarter, and for this kind of figliting I think the present caralry machinc-gun is the most efficient weapon that could be derised. It comes up almost unscen by the encmis, cspecially if it las an cscort of six or eight men, who can mask it completely until they arrire within close range. With senrecls a pause, it can conmence firing, pour in a rapid, deadly firc, und go on until the last noment with safety, and then bolt sway for its life, if it likes. All the cffect of this sudden and rspid setion mould be lost in the cose of a gun that had to morc with a limber and four horses attracting atten. tion, and which, when it came up, had to unlimber before it could commence firing, and then to limber up again in good time to get away, if the enemy came after it. I think the infantry ought to hare a gun of altogetlice another bind from that of caralrs. They ought to hare tools adapted for their special work. Let caralry hare a caralry galloping gun, and let infantry hare an infantry gun, and, if neces. sary, hare a general utility gun for the artillery if you like; but do not lare one to act for all. The lecturer says that "with caralry the machine-gun bas nothing in common, cxcept perliaps its power of rapid morcencnt, for caralry are supposed to act by shock, while machine-guns act by fire alone." Cavalry do not alwajs act by shock. I supposo througbout the Franco-Prussian campaign ney regiment you like to tube, liardly acted by ehock moro than half-a-dozen times in tho whole campaign; wlicreas pretty nearly erery das they mould be cagaged in holding and scizing defles, in occupjing adranced posts, on outpost duty, in hrossiug the cnems's flum, in attacking convoss, in loolding defiles when on the rear-guard in retreat. 'This is the usual eort of work which earalry hase to carry out on serrice, and for it the caralry machine-gun would bo the inost powerful aid that could be devised.

Captain Pallser : There is one part of the subject on which I wish to saj a word, as it hes only just been touched upon. That is, the wonderful shooting of the Maxim machine-nun. MIy opinion is, and it is a coming question, that this machinc-gun gircs the best shooting known, shooting that cannot be beaten eren by pickod marksmen in bodies. There has been somo rcmarkable shooting going on lately, which is new to this mecting, and about which I must be reticent to some cxteul, because it is under Gorernment supervision, aud is carricd out before the Committec. 'llis shooting has becn made not ouly at fixed marks, but in trarcrsing from one mark to another at ranges of from 600 to 975 yards. In one case an Officer who had nerer fired the gun before in 75 rounds mado 72 hits at 600 Jards. I say that the admirablo shooting of the machine-gun is the coming question, and I do not agree with Mr. Nordenfelt in the great merit of seattering firc. Theso weapone, when used in large numbers, whether made by MIr. Nordenfelt or Mr. Marim, or other nuehine-gun makers, must be brought to this perfection; and then the conditions of war will be clanged, because bs their uze ordinary soldicrs will be able to 
shoot as well and better, and in far greater rolume, than eren picked marksmen in numbers.

Lord Cinarees Beresfond: It ecems pcrilaps rather impertineat for a sailor to riso to speak on a subject so entirely connected with the sister Serrice, and particularly in the presence of eo many distinguished artillergmen; but I hare always taken such rery keen interest in this question that I hopo I may eay a few words. There is one expression that I think ought to bo altered in discussing this question, and it is one which has eroked a ccrtain amount of discussion to.night, namely, the name that it is giren to these reapong. I think they ought to be celled "machinerifles," because, directls jou get into the question of " machine-guns," jou lave a discussion as to how they are to be mounted. On tro occasions, at dlesandria, if I had had a machine-rife that could haro galloped, I could hare scat a certain amount of help, and it struck me whether it might not be possible to mount the machine-rifles, so that a horse or horses could gallop with then. Directly the question of "guns" and " batteries" is produced, the limber and trail is discussed, but keep this machine as a "rile," and it might be able to be put into action at a monent's notice. That is mhat passed through Captain Wilson, V.C.'s brain in the Soudan, becnuse the time he lost in haring to "Unlimber" and "Action right," "Action front," or "Action rear," the amount of time he so lost probably lost him a good many men, and prevented his being nblo to fight his gun at all. 'The object of the trro whecls, cither with infantry or caralrs, is to hare the gun alisass in action. It should be able to train orer its own wheels, and the mere dropping of the trail or the word "IIalt," "Right" or "Left rererse," should put the gun inme. diately in action. I think it would be a rery wise thing if the authorities would get rid of the expression " machine-gun," and as soon as possible use " machine-rille ;" for really, after all, this weapon is simply n cluster of long-range rilles. I must congratulate the lecturer on one of his suggestions, to the effect that something more practical should be done with this. It is rery gratifying to us who hare agitated for this arm for so many years to find an artillery Oficer morling out a paper of this description, coming as it docs from his branch of the Serrice, which we hare generally thought has been opposed to the machine-gun, principally, I beliere, beciuse it has becn called a gun. I say il is rery gratifying to find an artillery $O$ ficer who has brought the question so prominently before the public. The practical suggestion is, either that the obsoletc 9. pounder batteries should be formed into machinerille batteries, or Eomething of that charucter should be done, or that a Connitteo should be appointed in order to thresh this question actually out, because at present there are so mans different opinions on the matter; although 1 think gene. rally the Officers in the sister Scrrice acknowledgo that machine-guns lare a tery useful part to play in future wars. Of one thing I am perfectly certnin, that directly we produce smoleless porder, they will haro a most important part to plas. I thint the suggestion is terg risc, that this weapon should not supersede any arm of the Serrice. Why should it? It is a new arm; it has capabilitics that other arms hare not got. As far as rifle-firing goes-as a cluster of rifles-it should no more superscde any arm in the Scrrice than should our torpedo-boats or our submarine-boats supersede ironclads or cruizers. It is something clso that has got to be counted on when you go into action, and as far as jou can utilize it to knock 5our enemies into a cocked hat the better for you, but lake care that they d's not utilize it against you.. You must be prepared to mect likn with like, which is so important in all warfare. It would be a very serious thing if the German or any other arms were to take up the machine-gun question, and wo with nll our practical experence, haring found it so useful on so many occasions, were not to take it up and thresle it out as has becn proposed. Thero is nne thing more, in ny luublo opinion, and I hope 1 shall not be considered presumptuous in giving my opinion as a sailor; but I hase commanded these guns on shore as well as afloat, and I think one of the priucipal points to realize about the machine-gun is, that it slould be a unit. If you put it into batteries, if jou put it into trosps or into any section, or where the guns bare got to work together under an Offece as a battery or similar formation, you rould malo a mistake. They should bo essentially skirmisling clusters of rilles, and with each gun should be its oxn Officer. If you like to call them a "battery" or "troops," for marching in peace-time, do so, but the moment 
they are put into action they should work in separato units; one man might go to a clump of trees or a bridge and hold them, and another man to another place, an Oficer with ench unit, and do snmething equally good; but directly jou put them into a "batters," sou will hare a batters firing against them possibly. What is tlie result? You get hit on the flank and you are knocked out of action, as the French mitrailleuses were by the Prussians in 1870. The Germans lad a holy horror of the enitrailleuses instilled into them, and wbat did they tell their artillery to do? They said: "Never mind what elso you do, but as long as jou see tho mitrailleuse batlery, derote all your attention to it;" and as these mitrailleuscs all drew up in line and were worked as batteries, they were generally taken on the Aank, and two or three shells put them out of action. I think the lecturer has giren a most useful and instructire lecture, and I sincerely hope much good mas come of it, and tho muchine-rille introduced into the Serrice, as a new arm, to be utilized as tho Generol commanding a hrigade mas think fit.

The Cirsirxax: I am rery glad of the opportunity of following Iord Charles Beresford. I think lie needs no apology whaterer for addressing us on this subject, because we know the connection which he has had with machine-guns all along. The suggestion that he has made as to the change of term and the use of the guns in rery small units are, I think, most raluable. I should like to make a remark upon my omn appearance lierc, as an Oficer of artillery, in the chair. Sceing that tho lecturer also belongs to that branch of tho Serrice, it enight appear as if the artillery had something epccially to do with tho machinc-gun. But, in point of fact, except that the artillery administration-that is to say, the Director of Irtillery -lias to do with tho bringing out of the gun, the artillery arm has nothing further to do with what are called machine-guns; neither hare thes ang jealousy whaterer with regard to them, as Lord Charles Beresford seemed to suggest just now. I think they hare no jealousy whaterer as against them; on the contrars, at one time I think they rather claimed, or were anxious to hare more to do with them-to hare more share in their ananagement than his been subsequently accorded to them. I confess, at first my orn fecling was that the artillery could rery conreniently tako thern orer; but I hare come aray from that way of thinking. I do not think: there was sufficient ground for it. Iho weapon is an entirely different one from tho artillery weapon proper; its aims and its powcrs are entirely different. I think the obscrrations that have been made show that the action of the military authorities in putting these weapons in charge of the infantry and in charge of caralry regiments has done an enormous deal to popularize the weapon; and I cannot conceive that in any other was could Officers, non-commissioned officers, and men hare had the opportunity of making such intimate acquaintance with the wcapon, than by making it for the time being an integral portion of their regiments at $\Delta$ ldershot. I do not think it neccsarily follows that we should look to that us the end of all things as regards the organization of such wcapons. I think in a cawpaign it must remain a rule, that an infantry regiment or battalion, or a caralry regiment, will not always require to hare a machine-gun with it. It might go orer ground where such a gun could be absolutely of rerg little use, and therefore, I think, a General would wish to be able to at tach a machine-gun to an infantry regiment or to anj body of troops for a timc. In order to enable him to do this, be should hare a train of machinc-gune, each gun as a single unit, and ready to go by itself, to be detached for any number of duss to anj point where its serrices vere required. As regards the ofticering, it should be offecred much in the eame way as the mounted infantry ore officered. So far as the infuntry branch is concerned, it should be officered and manned in the came was as mounted infantry; that is to say, by men taken from the infantry. Sinilarly, Jou would require a bods of machinc-guns equipped to accompany caralrs, and that might be officered and manned by men taken specially from tho caralry, reads to be attached to any regiment which required its serrices, and in that way we should be able to get the greatest ralue out of the arm. In the meantime I think we hare erery reason to congratulate ourselses on the direction which lias been giren to affuirs, and be assured that we are in a rers good was, snd in ndrance of most other countrics.

Lieutenant Bessos: Thero appears to bo considerable differcince of opinion among caralry Offecrs about these galloping carriages, as to whether they are to be 
attached to caralry reginents or not. Caralry Offecrs present, I think, ure in farour of attaching them to cnvalry permanently. With regard to the two-wheeled carriage, there is a good deal of opinion hero in farour of it, as well as against it. Its readincs 3 in coming into action is certainly in its farour; but some gentlemen bare said that the horses are intended to bo unhooked, becauso if they aro not unhooked the firing will bccome bad orer 600 sards. If thes are to be unlooked at all they might as well hare the limber, because thes can come into action rery much more quickls with a limber and trail hooking on the limber than by unhook. ing the horses. [Captain BADEx Powell: Thes can unhook it in about ten seconds.] I think tho unlimbering can be done in two scconds. The horse artillery sometimes manage to get a round of blank off mithin about fire ecconds from the word "Halt," if thes aro asked to clo EO. There ras another objection made to . haring the guns in " balteries" or "troops," as I call them. I think, if for no other reason, they must be formed into troops for administrative purposcs alone. I hare said in inj lecture it is easy enough to get forecs to act separately which haro becu trained to act together, but it is a rery differeat matter to get those to act together which hare only been taught to act separately. Sereral gentlemen here think they ought to act together, and others separately. Probably the truth lies between the two: sometimes thes mill hare to act together, and at other times epparately; therefore hare them in troops by all weans, but hare them nble to act separately, if necessars. MIajor Snith, I think, got irrong about the weight of his carriage. II. proposed that the carriage should be drawn by two horses, and said the weight wrs 17 cirt. The most a liorso can draw at sueed is about 6 cwt.; tro horecs rould therefore draw abont 12 cwt. The carriage tliat I proposo weighs $25 \mathrm{cwt}$., and thereforo can be drawn by four horses. In horse artillery the weight of the carriage complete is 36 cwt., which is actually 6 ewt. per horse. General Arbuthnot eaid the ammunition mas geparated from the gun when the gun was unlimbered. I do not sce that that holds. The limber is 10 jards in rear of the gun, or nearer if desirable, and thero is also a considerable amount of ammunition, about 1,000 rounds, in the axletreo boxes. The total amount of ammunition carried in the galloping carriage is $1,6 \pm 6$ rounds. Against that you hare, in the carriage I propose, nearly 5,000 rounds in the limber and 800 in the asletrec bores, and you hare your 10-barrelled gun, which is very much more powerful. Gencral Arbutlinot also says that with the 10-barrelled gun ten bullets will hit one man. If the man chose to stand a jard off in front probably thes would; but at all ordinary ranges the bullets would scatter themselres, and not go within two feet of cach other. Mr. Nordenfelt will tell us how much ten bullets will scalter at 500 yards.

MIr. Nondesfelt: $\Delta$ bout sis feet the 10-barrel; the emaller gun scatters more.

Lieutenant Bexsox : I tried the 3-barrelled gun the other dity, and found that at 30 yards' range it scattered orer 5 feet during a fer ecconds of rapid fire from tho light carriagc.

Mr. Nordexfent: The smaller gung ecatter the most.

Licutenant Bexs0x: At any rate, tho ten bullets cannot hit ono man. Thes might hit ten men, perlaps, standing up togetler.

General Anectusor: Ten barrels fired ten times would hit ten men ten times.

Licutcnant IBexsoy : Thes would probably hit the men in rear after those in front had been killed. I think that is all I hare to eas.

The Crainsex: Gentlemen, we havo listened to a very carefully dram-up Iceture, for which I think Licuten:mt Benson deserres our vers hearty thanks. We hare also had a rery interesting discussion which will not be without its ralue. I am sure I slall onls be carrying out your wishes in thanking Licutenant Benson rery much for the good entertainment which he has giren.

1 Mr. Nordenfelt has since corrected this statement as follows:-"When tho ecattering gear is not used the 10-barrelled gun spreads orer 10 feet at 500 yards, and 20 feet at 1,000 yards. With scattering gear the spread can be adjusted up to a maximum of 100 feet at 1,000 yards' range." $-G$. B. 